\title{
Capturing the structural and compositional variability of Opalinus Clay: constraints from multidisciplinary investigations of Mont Terri drill cores (Switzerland)
}

\author{
Tilo Kneuker $^{1} \mathbb{D} \cdot$ Markus Furche $^{1}$
}

Received: 11 November 2020 / Accepted: 19 May 2021 / Published online: 2 June 2021

(c) The Author(s) 2021

\begin{abstract}
Opalinus Clay is considered a potential host rock for radioactive waste disposal. The Jurassic claystone formation is composed of several facies and subfacies types, which are characterized by varying amounts of quartz, carbonates (cements and fossils) and clay minerals. To provide samples for ongoing experimental and numerical studies, a complete core section was drilled in the Mont Terri rock laboratory. The lithological and structural variability (including tectonic fault structures) from borehole BAD-2 was investigated using a multidisciplinary approach including high-resolution geoelectric in situ borehole measurements, mineralogical/geochemical and (micro)structural analyses.

The lithological-compositional variability was captured by successfully applying a modified subfacies approach, which is independently confirmed by the geochemical data and ERT (Electrical Resistivity Tomography) measurements. The variability on the $\mathrm{cm}$ to $\mathrm{dm}$ scale perpendicular to bedding can be determined based on the mean resistivity and variation of amplitude. In particular, the facies transitions could be precisely located. The new results suggest that both shaly facies types form the homogenous part of the investigated section, whereas the sandy facies and especially the carbonate-rich sandy facies represent the more heterogeneous lithofacies types of the Opalinus Clay. The varying resistivity can be attributed to differences in clay mineral and carbonate content. Regarding the structural variability, brittle faults were observed with varying frequency throughout the investigated section. Most fault planes occur in the shaly facies types, some of them concentrate along heterogeneities on the subfacies scale. The striking reproducibility of the measurements and observations was confirmed by a comparison with boreholes drilled in parallel, indicating a rather low compositional-structural variability parallel to bedding. The applied multidisciplinary approach is well suited to depict the vertical and lateral variability of a claystone formation, allowing an assessment of the degree of homogeneity/heterogeneity based on the subfacies concept.
\end{abstract}

Keywords Claystone $\cdot$ Electrical resistivity tomography $\cdot$ Facies types $\cdot$ Microstructure $\cdot$ Mineralogical-geochemical analyzes $\cdot$ Mont Terri rock laboratory

\section{Introduction}

In countries, such as Switzerland, Germany and France, shale formations are considered potential host rocks for radioactive waste disposal. However, claystone exhibits a

This article is a part of the Topical Collection in Environmental Earth Sciences on "Sustainable Utilization of Geosystems" guest edited by Ulf Hünken, Peter Dietrich and Olaf Kolditz.

Tilo Kneuker

Tilo.Kneuker@bgr.de

1 Bundesanstalt Für Geowissenschaften Und Rohstoffe, Stilleweg 2, 30655 Hannover, Germany complex thermo-hydro-mechanical-chemical (THMC) coupling of many properties that are relevant for their barrier behavior. To address some of these issues, the Federal Institute for Geosciences and Natural Resources (BGR) perform experiments and measurements in the Swiss Mont Terri rock laboratory, which is located in the Jurassic Opalinus Clay (Bossart et al. 2017; Schuster et al. 2019). Furthermore, the study of Opalinus Clay is of great interest due to its properties that are representative for a barrier rock. It is also a crucial constituent for numerous potential applications in the oil and gas industry, in particular the storage of hydrocarbons or $\mathrm{CO}_{2}$ and for the safe disposal of high-level radioactive waste.

Rocks may show discontinuities, such as sedimentary structures and lithostratigraphic transitions towards 
heterogeneities including sand or carbonate layers and tectonic faults or fractures. Such discontinuities may have a large impact on the in situ stress state and on hydraulic and frictional properties (Minardi et al. 2016; Orellana et al. 2018a, b, 2019; Crisci et al. 2019). Fluids may penetrate along active fault zones and influence rock properties even at depths of several kilometers (e.g. Nesbitt and Muehlenbachs 1989; Zulauf et al. 1999; Boles et al. 2015). The multibarrier concept in claystone relies (amongst others) on the low hydraulic conductivity, the sorption properties and the fracture-sealing capabilities of the potential host rock formation. These properties depend on the mineralogical composition and the spatial distribution (rock fabric) of these constituents (Klinkenberg et al. 2009; Kaufhold et al. 2013; An et al. 2020; Zhang and Laurich 2020). A detailed characterization of discontinuities, heterogeneities and their lithological composition is therefore of high importance.

The primary aim of the two fully cored research drillings "AD" in the Mont Terri rock laboratory was to provide core samples for the collaborative BMBF-project "GeomInt" (Geomechanical Integrity of Host and Barrier Rocks - Experiment, Modeling and Analysis of Discontinuities).
The focus of this project are experimental-numerical analyses of the formation and development of discontinuities in rock salt, claystone and crystalline rocks (Kolditz et al. 2021). In addition to the sampling campaign for GeomInt, a multidisciplinary approach was applied to provide a detailed geological-geophysical characterization of the drill cores. The task was to characterize the rock units that had been drilled through, to precisely determine the locations of facies boundaries and to quantify the intra-facies variability. For this purpose (micro)structural and mineralogical-geochemical investigations were combined with borehole-based electrical resistivity tomography (ERT) measurements. To quantify the lateral variability, the results were compared to other boreholes of similar orientation and location (Fig. 1).

There are few attempts to systematically characterize intra-formational heterogeneity of claystone formations. In this context, the subfacies classification developed by Lauper et al. (2018) provides a framework for a detailed characterization of lithological intra-facies variations for the Opalinus Clay. For this approach, microstructural investigations are essential, as they provide information regarding the compositional-structural variability (e.g. Laurich et al. 2014;

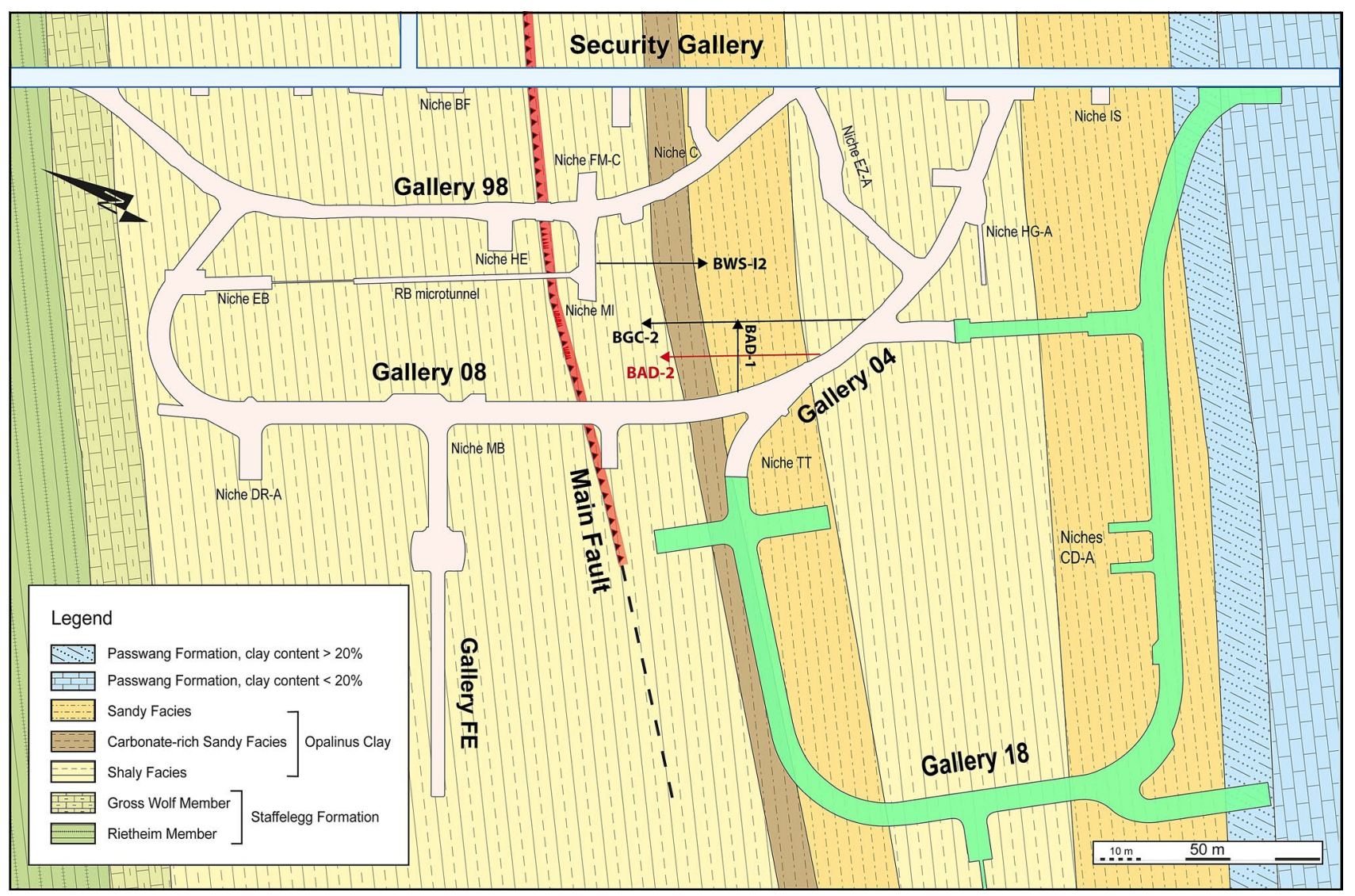

Fig. 1 Geological map of the rock laboratory including the location of the two AD boreholes (black: BAD-1, red: BAD-2) and adjacent boreholes BGC-2 and BWS-I2. The different facies types of the Opa- linus Clay can be recognized by the different shades of brown and yellow; the new Gallery 18 is highlighted in green. Map modified from Mont Terri Consortium (swisstopo) 
Kneuker et al. 2017), which are confirmed by the mineralogical-geochemical analyses, ideally applied in combination (e.g. Clauer et al. 2017; Kneuker et al. 2020). In addition, the BGR develops borehole tools with a high spatial resolution for in situ derived geophysical and geotechnical parameters. Especially ERT measurements have the capacity to characterize structures close to the borehole and to resolve rock variability with high accuracy. This, in combination with the introduction and standardization of the subfacies concept, will allow a more precise choice of claystone samples, e.g. for the experimental determination of parameters.

\section{Geological setting}

The Jurassic Opalinus Clay consists of dark grey argillaceous to light grey silty-sandy claystones that are subdivided into several lithostratigraphic units based on varying quantities of clay minerals, quartz and carbonates (Bläsi et al. 1996; Bossart and Thury 2008; Hostettler et al. 2017; Lauper et al. 2018). From the lowest to the uppermost stratigraphic position, these facies types include the lower shaly facies (shaly facies 1), the carbonate-rich sandy facies, the lower sandy facies (sandy facies 1), the upper shaly facies (shaly facies 2) and the upper sandy facies (sandy facies 2; not covered by the present study). Carbonates occur in the claystones either as biodetritus/fossils or as diagenetic cements, especially in the two sandy facies types. The Opalinus Clay was deposited in a shallow marine, epicontinental environment at the level of the storm wave base at ca. $20 \mathrm{~m}$ to $50 \mathrm{~m}$ water depth (Wetzel and Allia 2003). During Cretaceous burial, the Opalinus Clay experienced maximum palaeotemperatures of $75^{\circ} \mathrm{C}$ to $90{ }^{\circ} \mathrm{C}$ at a maximum burial depth of $1.35 \mathrm{~km}$ (Mazurek et al. 2006).

When compared with other Mesozoic rock formations, the Opalinus Clay is a macroscopically homogeneous formation with rather small lithological variability (this applies in particular to the shaly facies 1 ). On the $\mathrm{cm}$ to $\mathrm{dm}$ scale, however, several structural and compositional heterogeneities become evident. An example of a structural heterogeneity at the $\mathrm{m}$ scale is the Main Fault structure, outcropping in the Mont Terri rock laboratory (see below). The preferred alignment of phyllosilicates is related to bedding, which causes anisotropic hydraulic and mechanical properties (e.g. Gautschi 2017).

The Opalinus Clay investigated in this study originates from the Mont Terri rock laboratory, which is located next to the village of St. Ursanne in NW Switzerland. The total thickness of the Opalinus Clay in this area is ca. $130 \mathrm{~m}$. The layers are dipping with ca. $45^{\circ}$ towards SE. At the drilling site of the borehole BAD-2, the overburden amounts to $250 \mathrm{~m}$ (Fig. 1).

The rock laboratory is located within the southern fold limb of the NW-vergent Mont Terri anticline structure, in a special tectonic setting at the crossing of several structural elements, including the frontal part of the Jura fold belt and the roughly $\mathrm{N}-\mathrm{S}$ trending Rhine-Bresse zone. For details, see Nussbaum et al. (2011, 2017). Individual faults are commonly encountered throughout the rock laboratory (Jaeggi et al. 2017, 2020). A 1-3 m thick fault zone ("Main Fault") that is bounded by major fault planes including scaly clay and fault gouge was investigated in detail by several authors (Nussbaum et al. 2011; Laurich et al. 2014; Jaeggi et al. 2017; Kneuker et al. 2017). The inferred fault displacement is in the range of decameters. The relationship between fluid injection and fault displacement was investigated by an in situ experiment (Guglielmi et al. 2017; Jeanne et al. 2018). An injection pressure of ca. $4 \mathrm{MPa}$ led to a reactivation of the tested faults in the sub-mm range and a simultaneous transmissivity increase. In this context, Orellana et al. (2018a; b; 2019) conducted systematic laboratory studies regarding the frictional strength, mechanical stability, dilatancy and permeability of intact Opalinus Clay and simulated Opalinus Clay gouge.

Work towards a detailed litho- and biostratigraphical characterization of the rock sequence in the Mont Terri rock laboratory has been intensified in the last few years (e.g., Müller and Jaeggi 2012; Jaeggi et al. 2014; Reisdorf et al. 2014; Hostettler et al. 2017; Lauper et al. 2020). In addition to the established main lithofacies types Müller and Jaeggi (2012) and Lauper et al. (2018) introduced several subunits (subfacies types) to allow a consistent lithological classification of the Opalinus Clay. In our study, we present the results from (micro)structural investigations, geophysical borehole logging and the corresponding mineralogical-geochemical analysis. The aim is to characterize the small-scale lithological variability of the Opalinus Clay at high resolution by applying the subfacies concept (Lauper et al. 2018), including observations on brittle faults encountered in the different facies and subfacies types. To further validate the findings, the petrographic results were correlated with mineralogical-geochemical data and geoelectrical in situ borehole measurements.

\section{Sample material}

The two fully cored research boreholes (BAD-1 and BAD-2) with a hole diameter of $131 \mathrm{~mm}$ (resulting in a core diameter of $101 \mathrm{~mm}$ ) were drilled parallel (BAD-1) and perpendicular (BAD-2) to the sedimentary bedding, respectively. The 15.35-m long horizontal borehole BAD-1 was drilled in July 2018 and is located entirely in the lower sandy facies (sandy facies 1). This drill core is not part of the present study, as it was sampled in its entire length for a different experimental campaign of the GeomInt project (Kolditz et al. 2021). The BAD-2 borehole has a length of $27.0 \mathrm{~m}$ and was drilled in May 2019. The borehole is oriented perpendicular to the 
bedding (with a dip of $43^{\circ}$ ); thereby, crossing several important facies transitions of the Opalinus Clay (Fig. 1). The geological onsite mapping by swisstopo (Galletti and Jaeggi 2019) revealed the following stratigraphic sequence:

- $0.00 \mathrm{~m}$ to $4.75 \mathrm{~m}$ depth: upper shaly facies (shaly facies 2),

- $4.75 \mathrm{~m}$ to $19.40 \mathrm{~m}$ depth: lower sandy facies (sandy facies 1),

- $19.40 \mathrm{~m}$ to $24.57 \mathrm{~m}$ depth: carbonate-rich sandy-facies,

- $24.57 \mathrm{~m}$ to $27.00 \mathrm{~m}$ depth: lower shaly facies (shaly facies 1).

The BAD-2 drill core was sampled from $4.0 \mathrm{~m}$ to $14.8 \mathrm{~m}$ (mainly sandy facies 1) for laboratory experiments of the GeomInt project. The core samples were conditioned in aluminum foil and pressurized in special nitrogen-filled BGRliners (autoclaves) to avoid further alteration (as compared to Kaufhold et al. 2013). The cores allowed to study the important lithostratigraphic transition from the shaly facies 1 towards the carbonate-rich sandy facies (transition zone 1) and the so far poorly investigated transition from the carbonate-rich sandy facies towards the sandy facies 1 (transition zone 2). The drill core material from the intervals between $0.0 \mathrm{~m}$ to $4.0 \mathrm{~m}$ and $14.8 \mathrm{~m}$ to $27.0 \mathrm{~m}$ has been investigated at the BGR core repository in Hannover (Germany).

\section{Methods}

\section{Sampling}

On site, the nonoriented drill cores were first described visually. Sampling for thin sections and mineralogical-geochemical analyses was performed as indicated in Fig. 2. Samples for mineralogical-geochemical investigations and thin section analyses were collected perpendicular to bedding $\left(\mathrm{S}_{0}\right)$ and sealed air and gas tight in special coated aluminum foil in order to prevent artificial alteration, especially a drying/ dewatering of the sample material.

Samples for thin and polished section analysis were cut from 3 to $4 \mathrm{~cm}$ thick core disks, sampling for mineralogical-geochemical analyses were performed on ca. $2 \mathrm{~cm}$ thick core disks, to adequately capture the observed compositional variability at the subfacies scale. Approximately, $20 \mathrm{~g}$ of sample material was pulverized in a ring and puck-mill to powder with a particle size $<40 \mu \mathrm{m}$. For thin and polished sections, samples were carefully dry cut to avoid the formation of artificial microcracks and to prevent contamination with liquids. Fragile samples were impregnated with epoxy resin to prevent break-up and to further stabilize the sample during the preparation process.

\section{Microfabric and structural studies}

To investigate the microfabrics in the claystone samples, polished thin and thick sections were analyzed under transmitted and reflected light using a Leica DMRM polarization microscope. Optical polarization microscopes were used for structural analysis of the claystone in the $\mathrm{mm}$ to $\mu \mathrm{m}$ scale. Polished sections were investigated using a high-resolution scanning electron microscope (SEM). For the present study, a Quanta $600 \mathrm{~F}$ in low vacuum mode $(0.6 \mathrm{mbar})$ with an acceleration voltage of $20.0 \mathrm{kV}$ in backscatter mode was used. This SEM is equipped with the EDX detector system Apollo XL. The EDX detector has a spatial resolution of around $5 \mu \mathrm{m}$.

\section{Mineralogical-geochemical analyses}

The mineral phases of the claystone samples were analyzed using X-ray powder diffraction (XRD). A PANalytical MPD Pro with Bragg-Brentano geometry including a fine-structure copper tube was used. The apparatus is equipped with a variable divergence slit $(20 \mathrm{~mm}$ irradiated length), a $X^{\prime}$ Celerator detector (active length $0.59^{\circ}$ ) and a sample changer. By default, the samples consist of 1-2 g fine powder $(<40 \mu \mathrm{m})$. Depending on the analyzed phase, the detection limit ranges from $1-5 \mathrm{wt} \%$. For analytical details, see Ufer et al. (2012).

$\mathrm{X}$-ray fluorescence analysis (XRF) was used to quantify chemical elements from an atomic number of 9 (fluorine) upwards. The detection limit varies between $0.01 \mathrm{wt} \%$ and $1 \mathrm{wt} \%$ for major components and between $1 \mathrm{ppm}$ and $30 \mathrm{ppm}$ for trace elements. Before the analysis, the quantification of volatile constituents was carried out by heating of $1 \mathrm{~g}$ sample material at $\mathrm{T}=1030{ }^{\circ} \mathrm{C}$ for $10 \mathrm{~min}$ (loss on ignition, LOI). The sequential determination of 10 major and 31 trace elements was performed using a PANalytical Axios WD-XRF spectrometer, equipped with a rhodium source. For further details of the analytical procedure, see Reimann et al. (2014).

The determination of cation exchange capacity (CEC) was carried out according to the method of Meier and Kahr (1999), after calcite saturation of the sample material, based on a $\mathrm{Cu}(\mathrm{II})$ triethylentetramine complex ("Cu-trien method"). This parameter is a measure of smectite content, such as illite-smectite mixed layers (Frederickx et al. 2018). For the determination of cation exchange capacity around $1 \mathrm{~g}$ of sample material is required. According to Dohrmann et al. (2012), the analytical error for high-CEC bentonites is generally better than $\pm 3.9 \mathrm{cmol}(+) \mathrm{kg}^{-1}$, for natural Opalinus Clay the corresponding errors are likely to be lower. 


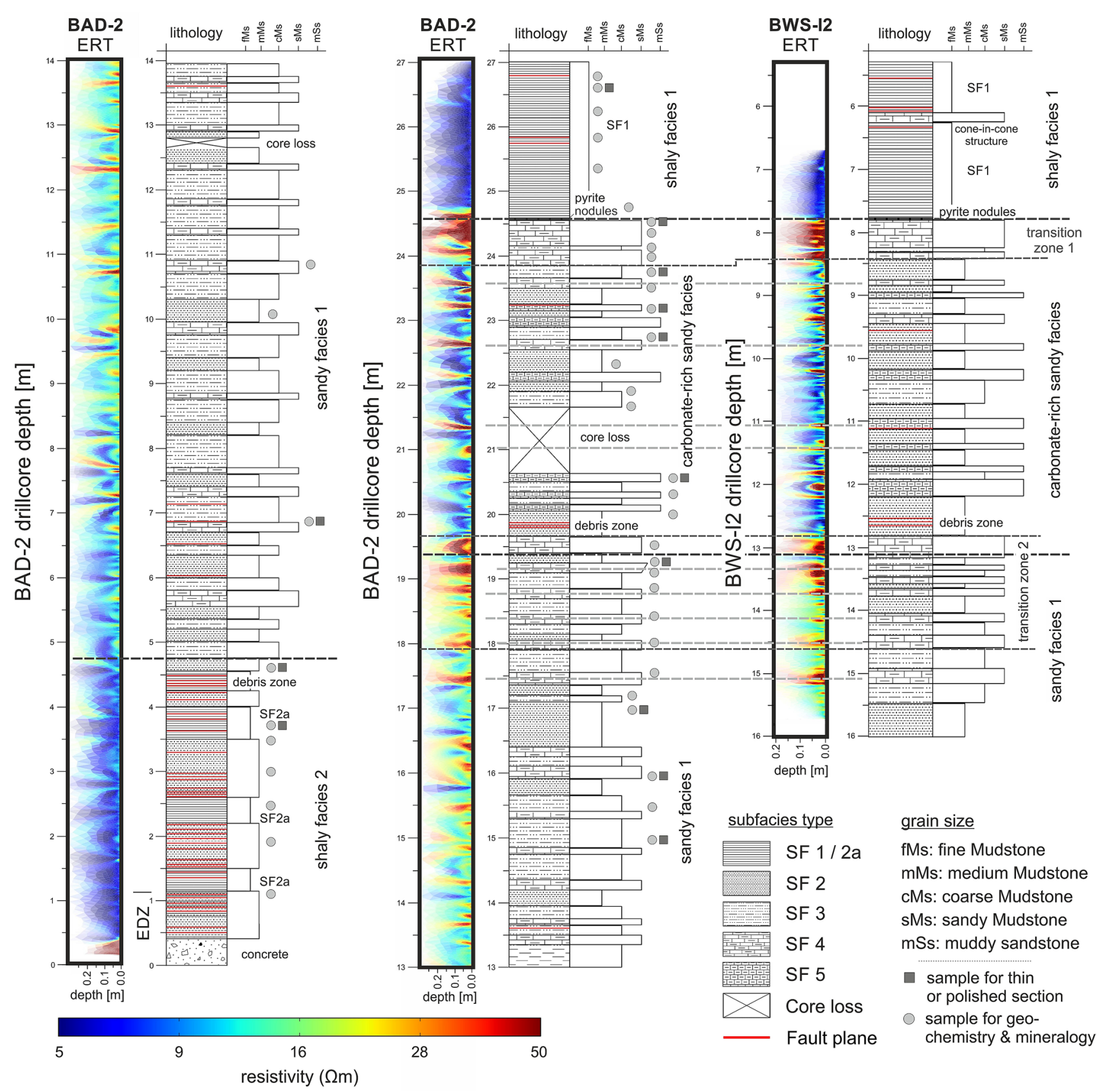

Fig. 2 Facies and subfacies distribution in comparison to the colorcoded 2D resistivity (ERT data) along the two boreholes BAD-2 and BWS-I2 with the encountered fault planes and lithological character-

\section{Geoelectric borehole measurements (ERT)}

To reveal the spatial resistivity distribution along the borehole axis, direct current geoelectrical measurements were performed using the high-resolution earth resistivity meter 4-point light $10 \mathrm{~W}$ (Lippmann Geophysikalische Messgeräte), controlled by the software GeoTest (Geophysik-Dr. Rauen). In this setup, the BGR borehole probe GB100-15 provides the necessary electric contact to the borehole istics. Locations of samples for thin section and geochemical analyses are indicated along the core. $E D Z$ excavation damaged zone, $S F$ subfacies types

wall. It consists of 100 electrodes with a spacing of $15 \mathrm{~mm}$ (Fig. 3b). For the measurements in adjacent boreholes BGC-2 and BWS-I2, the GB50-15 borehole probe with 50 electrodes and an electrode distance of $15 \mathrm{~mm}$ was used (Fig. 3a). Both tools have a diameter of $80 \mathrm{~mm}$ (for typical hole diameters of $86 \mathrm{~mm}$ ), but greater diameters can be adapted. The electrodes can be extended pneumatically for the required connection to the borehole wall. The spatial resolution is limited by $2 \times$ the electrode distance $(30 \mathrm{~mm})$, 

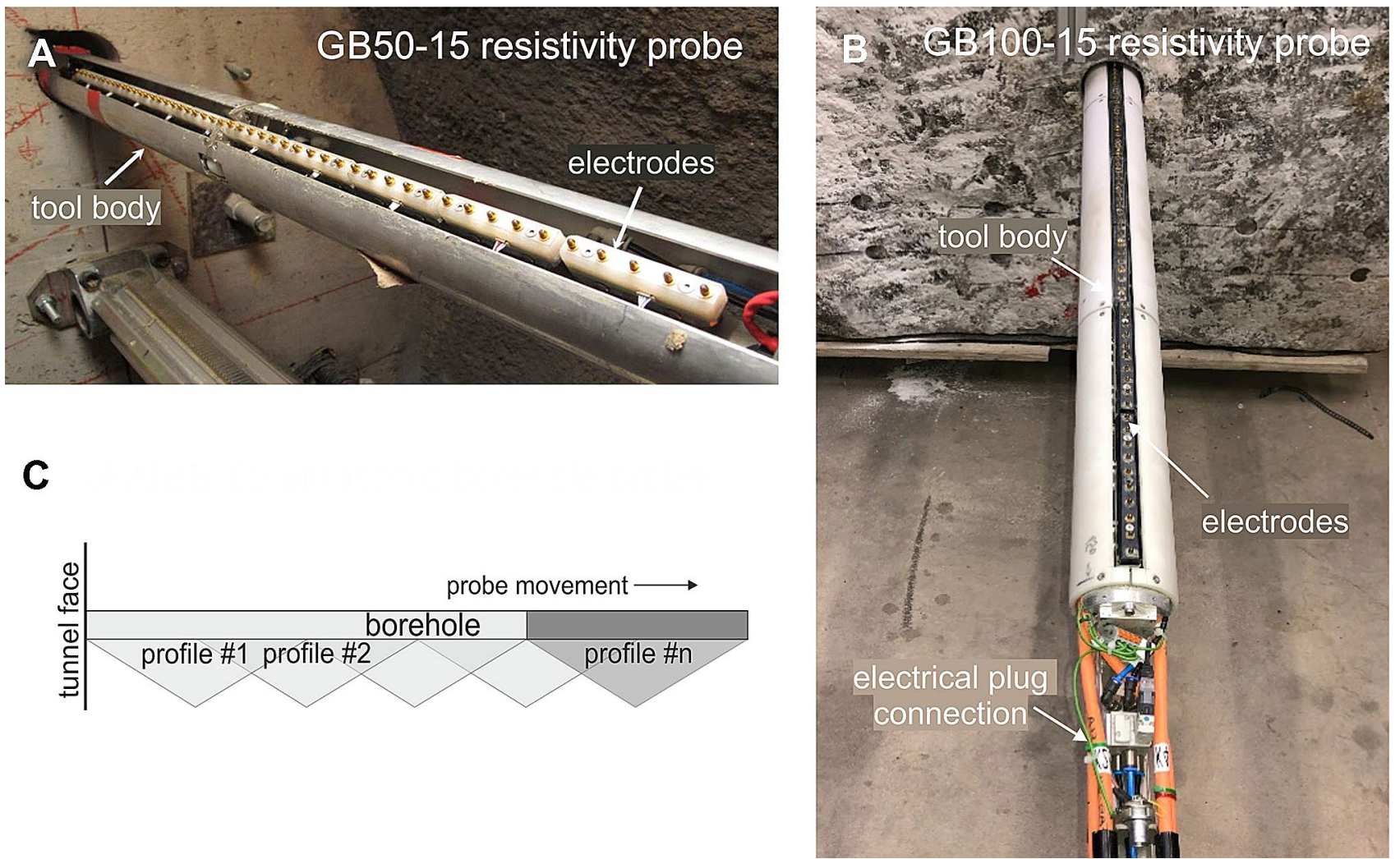

Fig. 3 A BGR GB50-15 resistivity probe for single hole measurements with 50 electrodes and an electrode distance of $15 \mathrm{~mm}$. B BGR GB100-15 resistivity probe for high-resolution single hole meas-

the maximum depth of investigation is about $30 \mathrm{~cm}$ perpendicular to the borehole wall. The chosen electrode configuration represents a Wenner- $\alpha$ setup.

The measurements commence at the tunnel surface. Because of the shotcrete lining, the first measured point is located at a borehole depth of $10 \mathrm{~cm}$. The probe is moved progressively down the borehole in distinct steps of $75 \mathrm{~cm}$ length. This results in a half side overlapping of the geoelectrical pseudosections (Fig. 3c). The measurements on borehole BAD-2 were performed in May 2019. Since the borehole is oriented perpendicular to the bedding, measurements were only taken in one orientation $\left(0^{\circ}\right.$, i.e. the electrodes are oriented upwards). A total of 35 individual profiles with half-sided overlapping were mapped.

A numerical inversion process is necessary for data analysis and interpretation. The measured apparent resistivities along the borehole are thus transformed into a spatial model, discretized into a distinct number of elements of homogeneous resistivity, taking into account the electrode geometry. The forward operator in the inversion process is generally obtained by finite-difference (FD) or finite-element (FE) methods. For our data, the non-commercial software package BERT (Boundless Electrical Resistivity Tomography) urements consisting of 100 electrodes and an electrode distance of $15 \mathrm{~mm}$. C Schematic representation of the ERT measuring sequence with half-sided overlapping profile measurements

developed by Th. Günther (Leibniz Institute of Applied Geophysics, Hannover) and C. Rücker (Technical University of Berlin) is used (https://gitlab.com/resistivity-net/bert). For further details, see Günther et al. (2006) and Rücker et al. (2006).

\section{Results}

\section{Petrography}

The investigated drill cores capture two of the five major facies types of the Opalinus Clay completely and two facies types partially (Figs. 1 and 2). For the present study, we applied the classification of subfacies types (SF) according to Lauper et al. (2018) including the newly defined subfacies type SF2a (see below). Each subfacies type is characterized by a distinctive color, grain size, (micro)fabric and lithology (Fig. 4).

From stratigraphic base to top (against the direction of drilling), the shaly facies 1 was encountered between $27.00 \mathrm{~m}$ and $24.57 \mathrm{~m}$ depth (Fig. 2). This facies type consists of homogenous, dark grey calcareous to silty-sandy 
Subfacies type 1 (SF1) (Lauper et al. 2018)

Dark grey, weakly bioturbated, homogeneous, argillaceous fine to medium grained mudstone with bioclastic fragments, enriched in horizons.

Subfacies type 2a (SF2a) (this work)

Dark grey, sparsely bioturbated, continuous to discontinuous planar-parallel-laminated, argillaceous-siliceous medium-grained mudstone, with sparse bioclastic fragments. Less sparsely to moderately cemented silt-rich laminaes in comparison to SF2.

Subfacies type 2 (SF2) (Lauper et al. 2018)

Medium-dark grey, sparsely bioturbated, continuous to discontinuous planar-parallel-laminated, argillaceoussiliceous medium to coarse-grained mudstone including sparse bioclastic fragments.

Subfacies type 3 (SF3) (Lauper et al. 2018)

Medium grey, moderately bioturbated, lenticular-laminated or interwoven, siliceous-argillaceous sandy mudstone with common bioclastic fragments.

Subfacies type 4 (SF4) (Lauper et al. 2018)

Medium-light grey, strongly bioturbated, flaser-bedded to homogenous siliceous-calcareous sandy mudstone with abundant bioclastic fragments.

Subfacies type 5 (SF5) (Lauper et al. 2018)

Light grey, churned, bioclastic, medium to coarse grained calcareous-sandy mudstone to limestone.
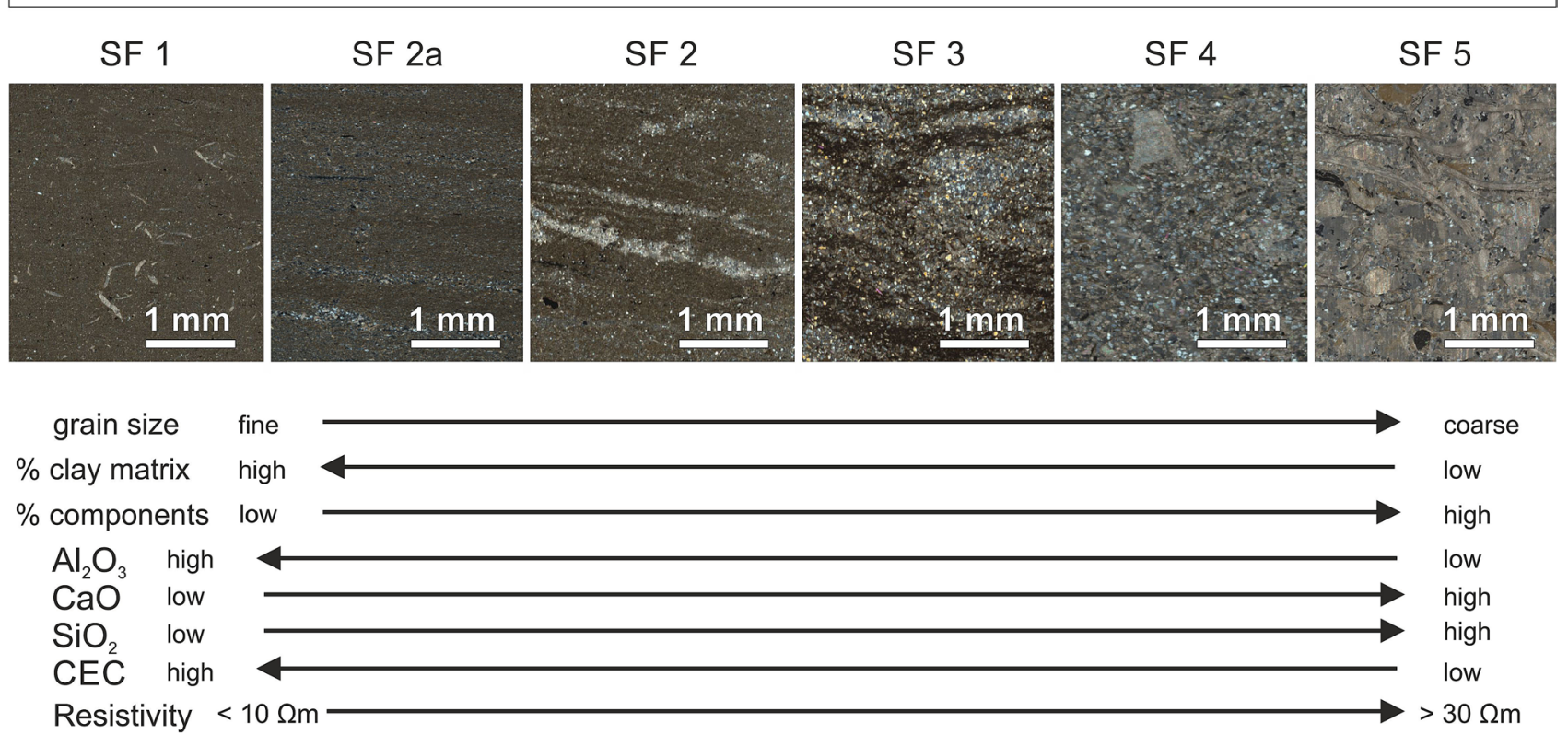

Fig. 4 Schematic figure summarizing the structural and geochemical trends for the different identified subfacies types of the Opalinus Clay including characteristic microstructures. Arrows indicate relative

mudstones including mica, pyrite and accumulations of biodetritus (Fig. 5a). The clay fraction is visible in thin sections as a fine-grained, brownish matrix, including up to $25 \mu \mathrm{m}$-sized flakes of muscovite and isolated quartz grains. Silty-sandy, detrital components are angular to subrounded quartz and feldspar with a grain size between $5 \mu \mathrm{m}$ and $15 \mu \mathrm{m}$. Framboidal pyrite occurs irregularly distributed in the clay-rich matrix or locally clustered (pyritizied burrow trends. All photomicrographs with crossed polarizers under transmitted light. For details see text. CEC cation exchange capacity, $S F$ subfacies type

structures). The shaly facies 1 is the most homogenous facies type of the investigated section. Here, in accordance with Lauper et al. (2018), only subfacies type SF1 was observed (see Fig. 2).

The base of the first carbonate layer is defined as the onset of the carbonate-rich sandy facies. This sharp lithostratigraphic transition towards the overlying carbonate-rich sandy facies is formed by light grey, flaser-bedded to 

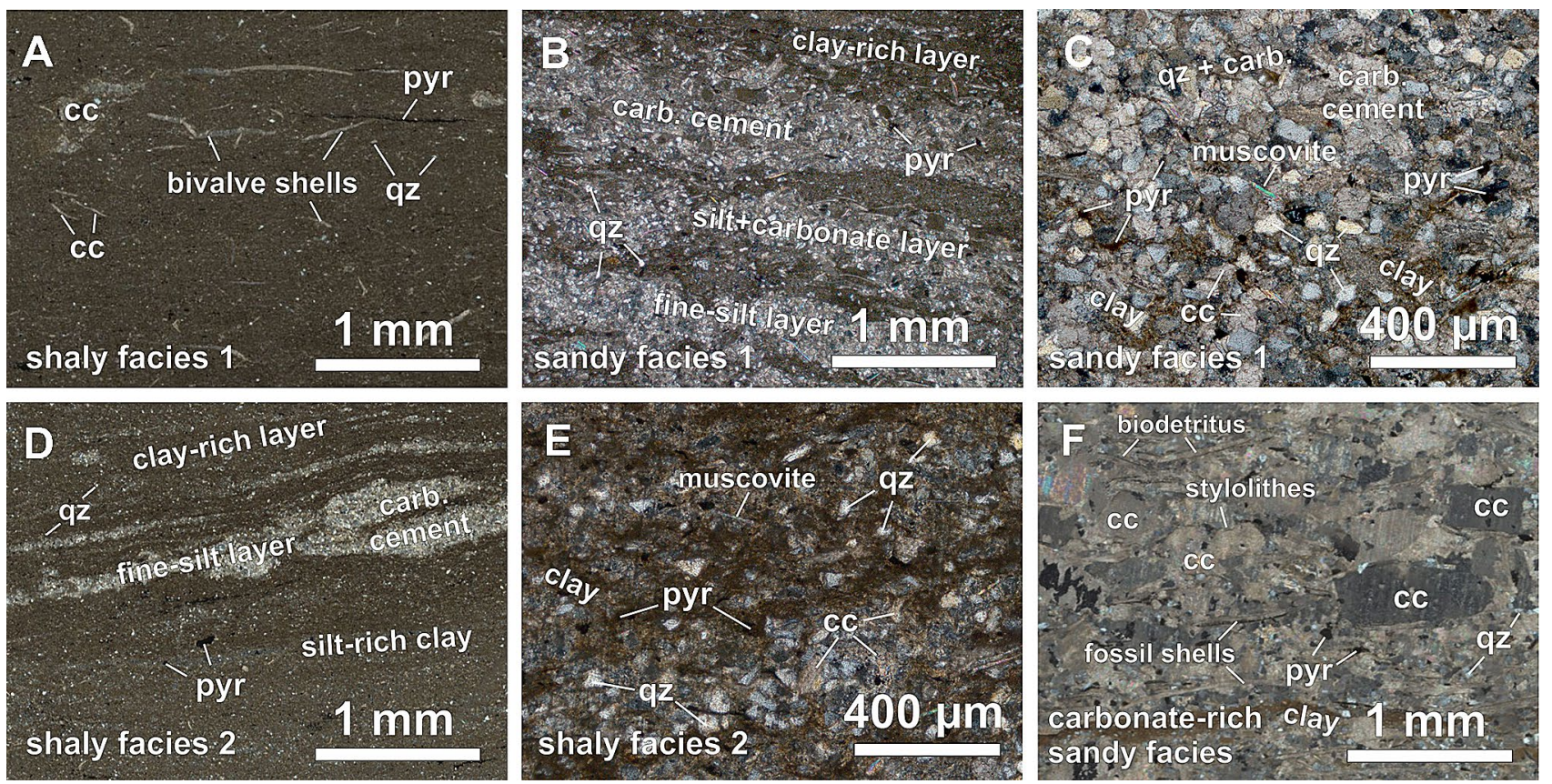

Fig. 5 Microphotographs of different facies types of Opalinus Clay under transmitted light with crossed polarizers. A Characteristic microstructure for the shaly facies 1: Overview shot including bivalve fragments, quartz grains (qz), calcite-rich (cc) biodetritus and tubelike pyrite burrows (pyr); sample 19Mt0062. B Characteristic microstructure for the sandy facies 1: Overview including alternating siltysandy and clay-rich layers; sample 19Mt0046. C Detail of a silt-rich, carbonate cemented interval showing calcite cement (cc), individual quartz grains (qz) and dark pyrite grains (pyr); sample 19Mt0045,

homogenous calcareous-siliceous layers (SF4) with few argillaceous-siliceous mudstone layers (SF2) between $24.57 \mathrm{~m}$ and $23.90 \mathrm{~m}$ drill core depth (transition zone 1). Larger fossil (echinoderm) remains and pyrite nodules are commonly found in this interval. The carbonate-rich sandy facies (from $24.57 \mathrm{~m}$ to $19.40 \mathrm{~m}$ ) includes dark grey, moderately to strongly bioturbated, calcareous, silty-sandy mudstone layers alternating with $\mathrm{cm}$ to $\mathrm{dm}$ thick, light-grey calcareous-siliceous lenses and layers. The latter consist of silt- to fine-sand-sized detrital quartz (grain size $>80 \mu \mathrm{m}$ ) and include abundant bioclastic fragments up to $2 \mathrm{~cm}$ in size (Fig. 5f). The carbonate-rich sandy facies is the most heterogeneous facies type at the Mont Terri site due to the contrasting occurrence of the argillaceous-siliceous subfacies type SF2 and both carbonate dominated subfacies types SF4 and SF5.

The more gradual transition from the carbonate-rich sandy facies towards the sandy facies 1 is located in borehole BAD-2 between $19.56 \mathrm{~m}$ and $17.85 \mathrm{~m}$ (transition zone 2). The transition is marked by thicker, medium to light grey, homogenous siliceous-calcareous bioclast-rich beds (SF4) with few argillaceous or siliceous interlayers (SF2 and SF3). The carbonate content is decreasing in favor of silty-sandy sandy facies 1. D Characteristic microstructure for the shaly facies 2 : Overview shot showing alternating clay-rich and quartz-rich fine-silt layers including carbonate cements; sample 19Mt0040. E Detail of a silt-rich domain including angular to subangular quartz grains, calcite cement (cc) and dark pyrite grains; sample 19Mt0041, shaly facies 2 . F Characteristic microstructure for the carbonate-rich sandy facies: Overview shot of a quartz-rich, carbonate cemented layer, including fossil shells, sparry calcite fragments (cc), dark pyrite grains (pyr) and stylolites; sample 19Mt0052

lenses and layers. In contrast to transition zone 1, pyrite nodules were not found in this interval. The sandy facies 1 is located in borehole BAD-2 between $19.40 \mathrm{~m}$ and $4.75 \mathrm{~m}$ (Fig. 2). This facies is composed of calcareous, silty-sandy mudstones alternating with numerous light grey, bedded or laminated sandstones and distinct biodetritus-rich layers or lenses (Fig. 5b). Sand layers can have thicknesses of one $\mathrm{mm}$ up to several $\mathrm{cm}$. Silty-sandy quartz grains (grain sizes around $40-50 \mu \mathrm{m}$ ) are commonly cemented by carbonates, however, albeit the cementing is not always continuous (Fig. 5c). In the sandy facies 1 the subfacies types SF2, SF3 and SF4 were observed. The gradual transition towards the overlying shaly facies 2 is characterized by a decrease of the lenticular-laminated subfacies type 3 .

The shaly facies $2(4.75 \mathrm{~m}$ to $0.00 \mathrm{~m})$ is characterized by a dark grey, argillaceous to silty mudstone containing mica, pyrite and quartz grains with grain size between 20 and $35 \mu \mathrm{m}$. This mudstone is intercalated with light grey, $\mathrm{mm}$ to $\mathrm{cm}$ thick silt layers (Fig. $5 \mathrm{~d}$ ), which are not continuously cemented with calcite. When compared with the shaly facies 1 , the shaly facies 2 shows a higher amount of silt-grained clastic components and less biodetritic fragments (Fig. 5e). Disseminated pyrite occurs throughout the clay-rich 
intervals. In the shaly facies 2 the clay-rich subfacies types SF2 and SF2a were observed. The subfacies type 2a (SF2a) has been newly defined in the present study; it consists of a dark gray, sparsely bioturbated, planar-parallel-laminated, argillaceous-siliceous medium-grained mudstone (Fig. 4). It represents an intermediate type between SF1 and SF2, with fewer silt-rich laminaes when compared with SF2.

\section{Structural record}

Brittle faults were observed with different frequency in all facies types. Most fault planes occur in the shaly facies 1 and 2, with a high fault density of $6-9 \mathrm{~m}^{-1}$ for the latter (Fig. 6g). The artificial fracture pattern of the excavation damaged zone (EDZ) was observed up to $1.5 \mathrm{~m}$ borehole depth (Fig. 6a). In this interval, slickensides of shear fractures and plumose structures (indication for artificial tensile fractures) are visible on the joint planes of the drill cores. Fractures follow mainly the bedding plane $\mathrm{S}_{0}$ (ca. $150 / 45^{\circ}$ ) or cut them at a low angle of $5^{\circ}$ to $20^{\circ}$ (Fig. 6h). In this zone, small-scale faults including slickensides and scaly lenses were observed. This includes a debris zone at ca. $4.3 \mathrm{~m}$ drill core depth (Fig. 6d), where fragments with polished surfaces or striations are occurring. The shaly facies 1 shows lower fault densities (between 2 and $3 \mathrm{~m}^{-1}$ ), the brittle faults show a dip of $15^{\circ}$ to $30^{\circ}$ relative to the borehole axis. Fault surfaces in the shaly facies 1 are relatively smooth or almost perfectly planar and show a mirror-like polishing or well-developed striation with step-like elevations (risers) (Fig. 6b). At $26.75 \mathrm{~m}$, a $5 \mathrm{~mm}$ thick calcite vein was observed in close association to a slickensided shear plane (Fig. 6c). Calcite fibers are oriented subperpendicular to the fault plane; no clear median line could be observed. The slickenside lineation on striated surfaces indicates dip-slip movements, step-like risers on fault planes point to reverse or thrust faults. Fault density decreases in the sandy facies 1 and in the carbonate-rich sandy facies type. Fault dip relative to $S_{0}$ is between $0^{\circ}$ and $15^{\circ}$, two faults show elevated dip angles $>30^{\circ}$. Discontinuity planes are more irregular. Individual faults are characterized by a more or less distinct slickenside lineation (Fig. 6f). The step-like risers show an increased height as compared to the investigated samples from the shaly facies 1 (Fig. 6e). The wavy fault surfaces reflect the imprint of underlying early diagenetic nodules and mechanically strong cemented sedimentary structures that formed during sediment compaction.

When relating fault distribution to the individual subfacies types, the trend towards a concentration of faults in the shaly intervals is confirmed: Most fault planes were observed in the clay-rich subfacies types SF1, SF2a and $\mathrm{SF} 2$. Even in the sandy facies 1 and the carbonate-rich sandy facies, faults are more common in SF2 than in SF3. In SF4 and SF5 no faults were observed in BAD-2. In case of the homogenous shaly facies 1 , the majority of bedding parallel faults occur where no lithological heterogeneities are present. In the other facies types, faults commonly occur next to the interface between individual subfacies types, reflecting differences in mineralogical composition and material strength (Fig. 2). In this context, the debris zones near the transition from shaly facies 2 to sandy facies 1 (between 4.2 and $4.4 \mathrm{~m}$ ) and the debris zone next to the transition from sandy facies 1 towards the carbonate-rich sandy facies at 19.8-19.9 m drill core depth can be seen. In the parallel borehole BWS-I2, a similar debris zone with fragments showing more or less developed slickensides from 12.55 to $12.80 \mathrm{~m}$ is present (Fig. 2). Material derived from these zones was fragmented presumably by drilling-related stress into $\mathrm{cm}$ sized diamond shaped chips.

\section{Mineralogical-geochemical rock composition}

Qualitative whole rock XRD analyses revealed a composition that is typical for claystones: Quartz and calcite is present as main components in all samples; detected clay minerals are illite, kaolinite and illite-smectite mixed layer minerals. Other minor constituents include chlorite, pyrite, feldspar and siderite. Gypsum as evidence for artificial alteration processes was not detected in any of the analyzed samples. In addition to these minerals, varying amounts of ankerite (calcium iron carbonate) and kutnohorite (calcium manganese carbonate) were detected in samples from the sandy facies 1 and the carbonate-rich sandy facies.

The chemical composition of the whole rock samples was determined by wavelength dispersive $\mathrm{X}$-ray fluorescence analysis (XRF) and is presented as box and whisker plots (Figs. 7 and 8) for the individual facies and subfacies types. Measured values can be found in the supplementary material. The most striking trend is a steady increase in the $\mathrm{SiO}_{2}$ content from the shaly facies 1 towards the carbonate-rich sandy facies and the sandy facies 1 (Fig. 7). The shaly facies 1 and 2 are both characterized by a relatively uniform $\mathrm{SiO}_{2}$ content around $45 \mathrm{wt} \%$ to $55 \mathrm{wt} \%$. The highest $\mathrm{SiO}_{2}$ content of $66 \mathrm{wt} \%$ was measured in a sample from the sandy facies 1 . In contrast, the lowest value of $28 \mathrm{wt} \% \mathrm{SiO}_{2}$ was obtained in the basal part of the carbonate-rich sandy facies (transition zone 1), documenting the dominance of carbonates in this interval (Fig. 7).

The $\mathrm{Al}_{2} \mathrm{O}_{3}$ content is consistently high for the shaly facies types 1 and 2. It varies on average between $17 \mathrm{wt} \%$ and 20 wt $\%$ for these clay-rich intervals (Fig. 7). In the investigated profiles inside the Opalinus Clay, the $\mathrm{Al}_{2} \mathrm{O}_{3}$ content is mainly linked to the occurrence of alumosilicates like clay minerals. For the sandy and carbonate-rich sandy facies types, the $\mathrm{Al}_{2} \mathrm{O}_{3}$ content varies on average between $6 \mathrm{wt} \%$ and $12 \mathrm{wt} \%$. The most pronounced variation was recorded in the carbonate-rich sandy facies (and the two transition zones), where 

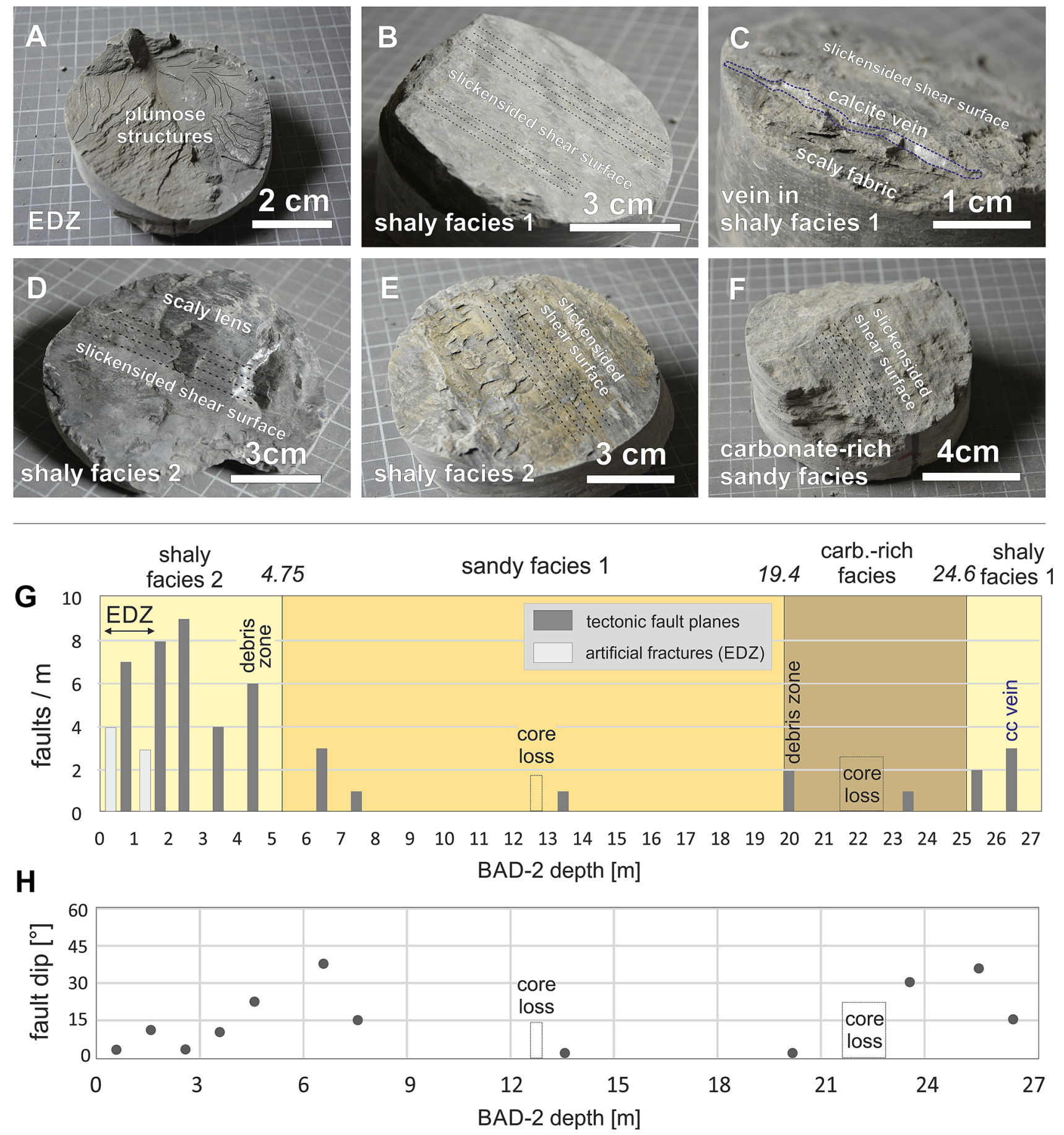

Fig. 6 Deformation structures and fault data from drill core BAD2. A Fan shaped plumose structures, characteristic of artificial EDZ fractures; drill core depth $0.85 \mathrm{~m}$. B Highly polished and planar slickensided shear plane in the shaly facies 1 of Opalinus Clay; drill core depth $25.76 \mathrm{~m}$. C $5 \mathrm{~mm}$ thick calcite vein associated with a shear plane; drill core depth $26.75 \mathrm{~m}$. D Scaly lenses and slickensides in the shaly facies 2 ; drill core depth $4.3 \mathrm{~m}$. E Slickensided shear plane in the shaly facies 2 , note the increased height of the step-like risers; drill core depth $1.76 \mathrm{~m}$. F More wavy, irregular fault plane of a steep fault plane from the carbonate-rich sandy facies, including a less distinct slickenside lineation; drill core depth $23.2 \mathrm{~m}$. G Histogram showing the frequency of artificial fractures and fault structures along borehole depth in meter intervals. Increased fault density is visible for the shaly facies 2, in parts overlapping with the EDZ. H Fault dip along the borehole axis of BAD-2; relative to borehole axis. $c c$ calcite, EDZexcavation damaged zone 
Fig. 7 Boxplots showing the distribution of selected major and trace elements for the individual facies types of the Opalinus Clay and the two transition zones (tz). The measurements were made by XRF on whole rock samples. The length of the whiskers corresponds to the 10th and 90th percentile. $s h$ shaly facies, $c r$ carbonate-rich sandy facies, $s a$ sandy facies
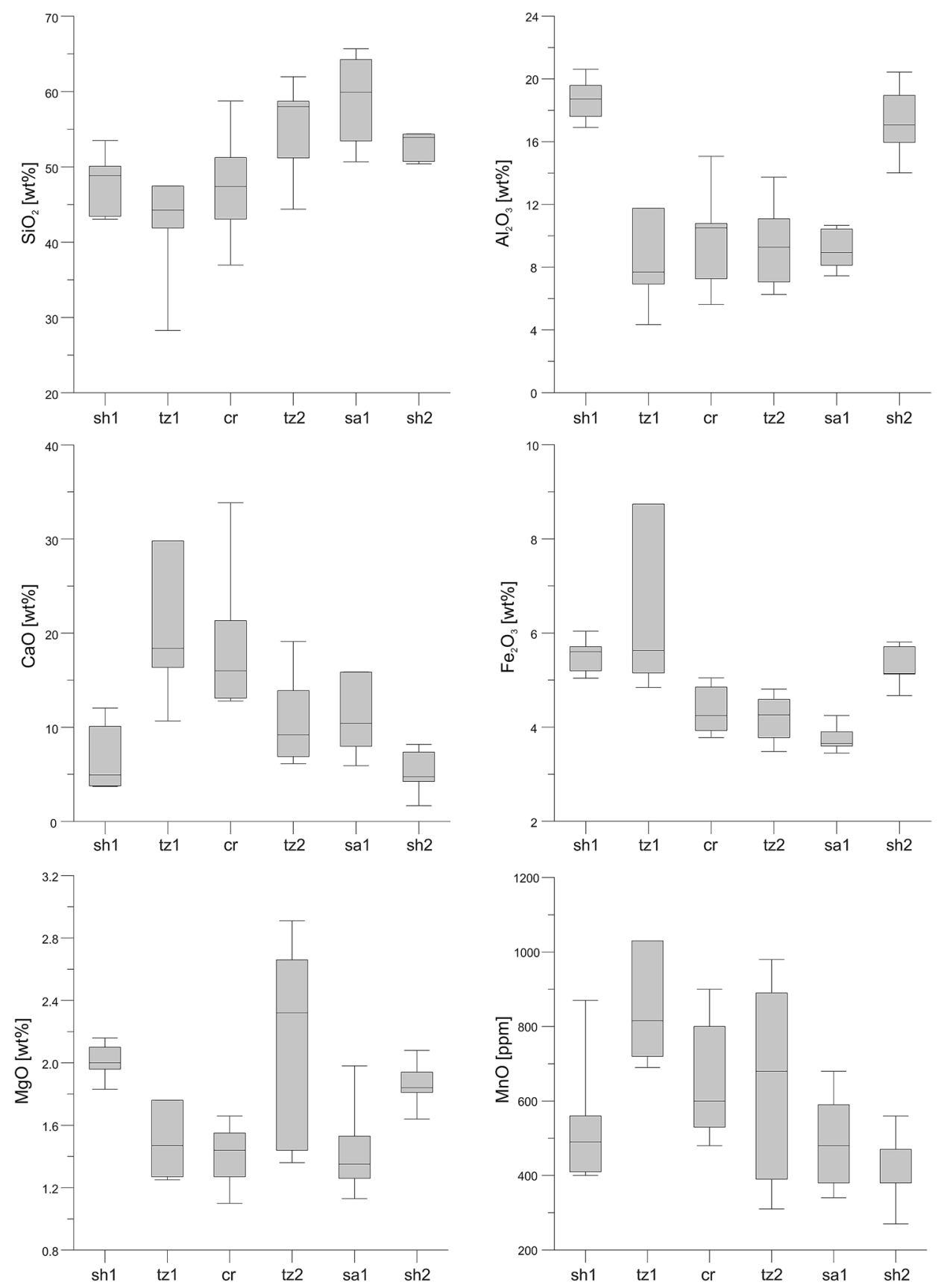

the content of $\mathrm{Al}_{2} \mathrm{O}_{3}$ varies between $4 \mathrm{wt} \%$ and $15 \mathrm{wt} \%$. The $\mathrm{CaO}$ content remains relatively constant $<10 \mathrm{wt} \%$ for the shaly facies 1 and 2 (on average $5.3 \mathrm{wt} \%$ ). The highest amount of $\mathrm{CaO}$ (33.8 wt\%) was measured in a sample from the carbonate-rich sandy facies (Fig. 7). When compared with the carbonate-rich sandy facies, the sandy facies 1 has a lower averaged $\mathrm{CaO}$ content (10.7 wt $\%$ vs. $17.2 \mathrm{wt} \%)$. An increase in $\mathrm{CaO}$ is documented by XRF data for the base of the carbonate-rich sandy facies (transition zone 1).

The $\mathrm{Fe}_{2} \mathrm{O}_{3}$ content varies in a narrow span (3-6 wt \%) for all facies types analyzed in the present study (Fig. 7). Slightly increased values ( $>5 \mathrm{wt} \%$ ) can be found in the shaly facies types 1 and 2, whereas values are reduced in the sandy facies $1\left(<5 \mathrm{wt} \% \mathrm{Fe}_{2} \mathrm{O}_{3}\right)$. An exception is present at the base of the carbonate-rich sandy facies (transition zone 1), where increased values between $5.0 \mathrm{wt} \%$ and $8.7 \mathrm{wt} \% \mathrm{Fe}_{2} \mathrm{O}_{3}$ were obtained. This is consistent with the occurrence of pyrite nodules and enrichments of siderite in this interval.

$\mathrm{MgO}$ is elevated in both shaly facies types (around 2 $\mathrm{wt} \%)$, whereas slightly reduced values $(<1.6 \mathrm{wt} \% \mathrm{MgO})$ occur in the carbonate-rich sandy and the sandy facies 1 . This indicates that $\mathrm{MgO}$ is mainly restricted to the clay-rich matrix of the Opalinus Clay. An exception is the transition zone 2 at the top of the carbonate-rich sandy facies, showing 
Fig. 8 Boxplots showing the distribution of $\mathrm{Zr}$, selected major elements and the cation exchange capacity (CEC), subdivided into facies and subfacies types (SF). The measurements were made by XRF on whole rock samples. The length of the whiskers corresponds to the 10th and 90th percentile. $s h$ shaly facies, $c r$ carbonaterich sandy facies, $s a$ sandy facies, $t z$ transition zone, $S F$ subfacies type
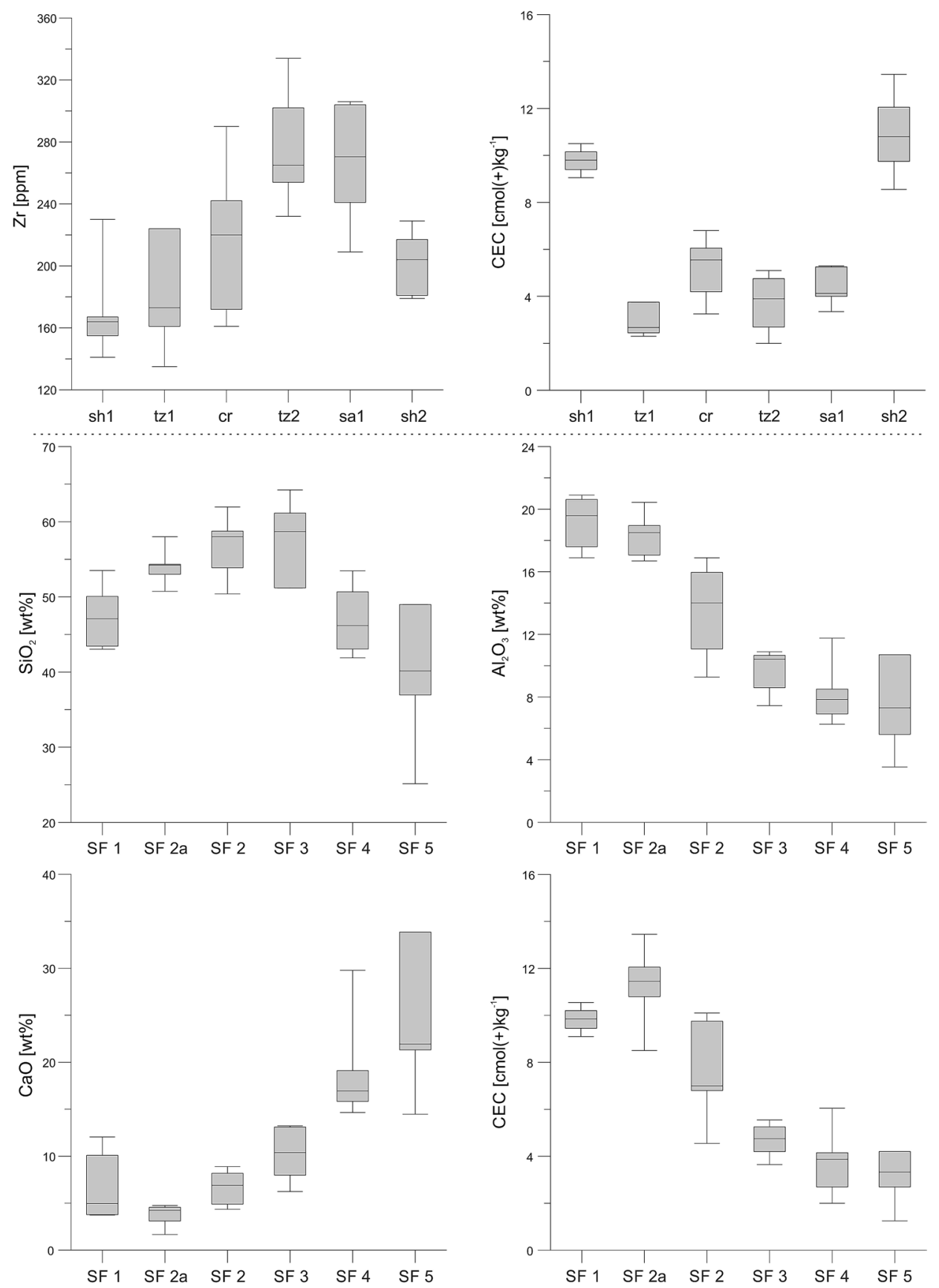

increased $\mathrm{MgO}$ values of averaged $2.4 \mathrm{wt} \%$ (Fig. 7). Here, $\mathrm{MgO}$ occurs most probably in association with carbonate phases, as XRD analyses revealed the presence of ankerite, a mineral that includes varying amounts of $\mathrm{MgO}$. In contrast to $\mathrm{MgO}, \mathrm{MnO}$ is clearly bound to the carbonate-rich parts of the investigated profile (Fig. 7). The shaly facies types 1 and 2 show values $<600 \mathrm{ppm}$. Increased $\mathrm{MnO}$ values are present at the base and at the top of the carbonate-rich sandy facies (transition zones 1 and 2), which is consistent with the presence of kutnohorite (calcium manganese carbonate), identified by XRD analyses.
$\mathrm{Zr}$ shows a steady increase towards the sandy facies 1 . The highest values $>320 \mathrm{ppm}$ were found in the transition zone 2 (Fig. 8). This corresponds well with the petrographic observation of increased detrital input in this interval. The shaly facies 2 , as compared to the shaly facies 1 , shows increased $\mathrm{Zr}$ values (200 ppm vs. $160 \mathrm{ppm}$ on average), which fits well with the occurrence of thin silt or sand layers (subfacies types SF2 and SF2a) in shaly facies 2.

The cation exchange capacity (CEC) varies within a relatively narrow range between $8.5 \mathrm{cmol}(+) \mathrm{kg}^{-1}$ and $11.5 \mathrm{cmol}(+) \mathrm{kg}^{-1}$ for the shaly facies 1 . The shaly facies 
2 shows comparable values of $11.8 \mathrm{cmol}(+) \mathrm{kg}^{-1}$ on average. In contrast, low values between $2 \mathrm{cmol}(+) \mathrm{kg}^{-1}$ and 5.3 cmol $(+) \mathrm{kg}^{-1}$ were measured in the sandy facies 1 (Fig. 8). Such reduced values correlate well with a low content of alumosilicates in this facies type. The carbonate-rich sandy facies shows the largest variability of all types of facies studied in the BAD-2 drill cores. Here, the CEC vary between $1.3 \mathrm{cmol}(+) \mathrm{kg}^{-1}$ and $7 \mathrm{cmol}(+) \mathrm{kg}^{-1}$, reflecting the heterogeneous composition of this facies type.

The boxplots in Fig. 8 show the content of selected elements and parameters $\left(\mathrm{SiO}_{2}, \mathrm{Al}_{2} \mathrm{O}_{3}, \mathrm{CaO}\right.$ and $\left.\mathrm{CEC}\right)$ broken down into the six subfacies types. The trends in major element composition as described above are reflected by the results summarized in Fig. 4. The decrease in $\mathrm{Al}_{2} \mathrm{O}_{3}$ with increasing $\mathrm{CaO}$ and a corresponding decrease in CEC is clearly confirmed by the data. $\mathrm{SiO}_{2}$ content is more variable and shows a slight increase from SF1 to SF2, a larger scatter in SF3 and a clear decrease in the carbonate-rich subfacies types SF4 and SF5, confirming the petrographic observation of a steady increase in carbonates for these subfacies types.

\section{Facies-related electrical resistivity}

Electrical resistivity measured in situ along the borehole BAD-2 varies by an order of magnitude, i.e. between $5.0 \Omega \mathrm{m}$ and $50 \Omega \mathrm{m}$ (Fig. 2). Up to $50 \mathrm{~cm}$ borehole depth, the shotcrete lining of the gallery wall can be recognized as a high-resistivity structure. Below that, the resistivity in the shaly facies 2 is ca. $5-10 \Omega \mathrm{m}$. The geological investigations revealed the presence of artificial EDZ fractures to a depth of $1.5 \mathrm{~m}$, which are not visible in the resistivity profile of BAD-2. From $4.7 \mathrm{~m}$ borehole depth onwards, the resistivity in the sandy facies 1 rises gradually up to $20 \Omega \mathrm{m}$. Embedded in this basic structure are narrow layers characterized by a high resistivity up to $30 \Omega \mathrm{m}$. A comparison with petrographic data reveals that high-resistivity layers correlate well with the carbonate-rich subfacies types SF4 and SF5 (Fig. 2). Sandy layers and lenses including subfacies types SF2 and SF3 show intermediate resistivity. Between $18.5 \mathrm{~m}$ and $19.4 \mathrm{~m}$ (transition zone 2, towards the carbonate-rich sandy facies) there is a striking high-resistance range ( $>40$ $\Omega \mathrm{m})$, after which the resistance level drops significantly down to $10 \Omega \mathrm{m}$, again with embedded high-resistance layers. Between $23.9 \mathrm{~m}$ and $24.6 \mathrm{~m}$ (transition zone 1, towards the shaly facies 1) a second distinct high-resistance range $>40$ $\Omega \mathrm{m}$ is reached, after which a sharp drop to values $<10 \Omega \mathrm{m}$ can be observed. This level is maintained in the shaly facies 1 down to the bottom of the borehole without significant variation. The low resistivity can be attributed to the clay dominated subfacies type SF1 (Figs. 2 and 4).

For further analyses, resistivity curves were extracted from the calculated 2D models along the borehole axis of BAD-2. The blue graph in Fig. 9 shows the corresponding resistivity curve for a radial depth of $5 \mathrm{~cm}$ from the borehole wall. The positive and negative peaks in the resistivity curve can be caused by either lithological changes in the claystones (such quartz-rich sandy or carbonate interlayers) or due to fracturing and water saturation effects. A comparison with the adjacent boreholes BGC-2 and BWS-I2 revealed a good reproducibility of the geoelectric signal. BGC-2 runs
Fig. 9 Comparison of the resistivity curves for the boreholes BAD-2 (blue graph) and BGC-2 (red graph) at a distance of $5 \mathrm{~cm}$ perpendicular to the borehole wall. The graph from BAD-2 was shifted $3.6 \mathrm{~m}$ in borehole direction, due to the different drilling locations. Different facies types are indicated by different shades of brown and yellow

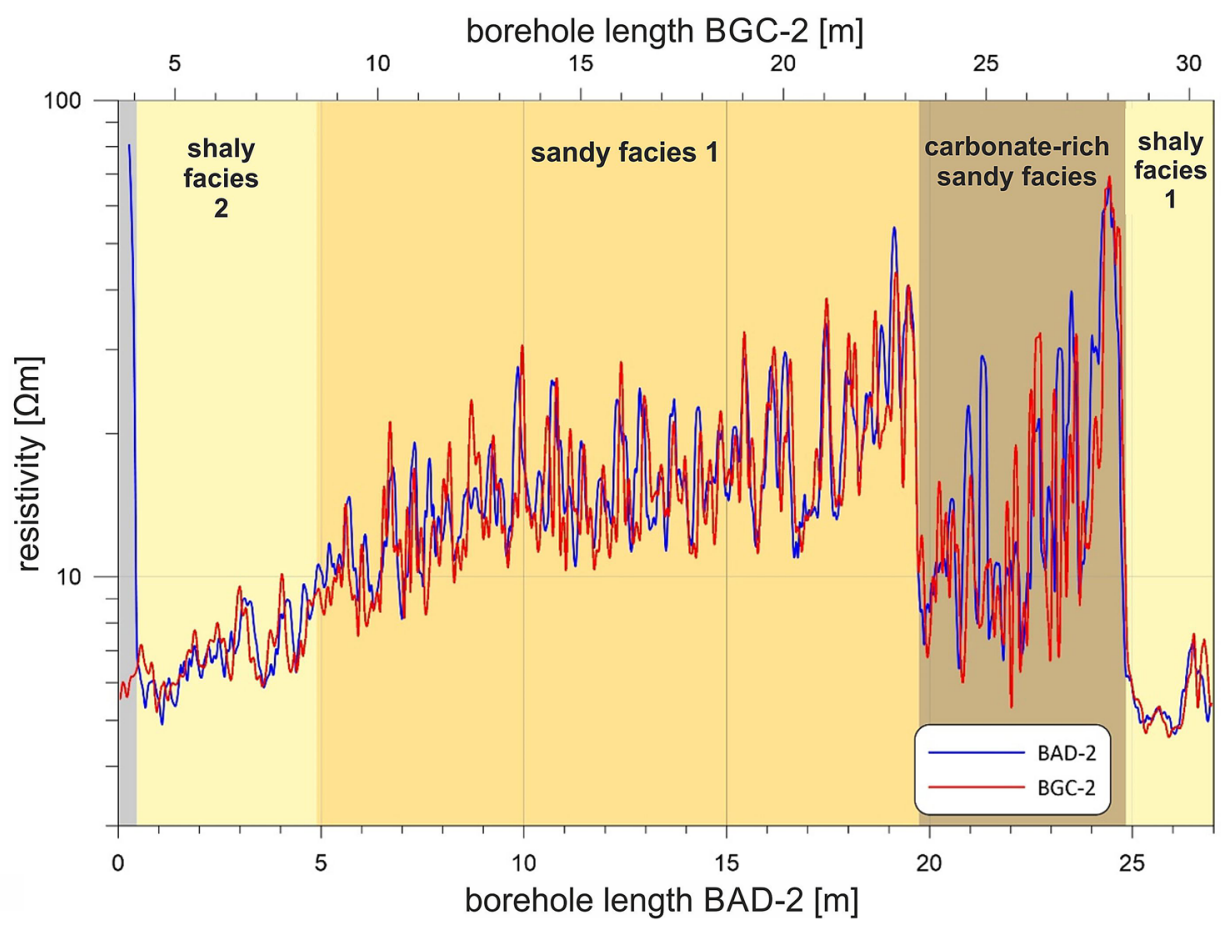


parallel to borehole BAD-2 with a horizontal distance of ca. $4 \mathrm{~m}$. The measurements in that borehole had been carried out almost two years earlier in September 2017 with the GB50-15 probe, which is half as long. For this reason, the radial model depths of the electrical resistivity in BGC-2 are only $20 \mathrm{~cm}$. Figure 9 shows the resistivity curves for $5 \mathrm{~cm}$ depth perpendicular to the borehole wall for both boreholes. With few exceptions, almost the same structures were detected, especially the thicker sand layers inside the sandy facies 1 are well traceable. For resistivity curves inside the carbonate-rich sandy facies, the correlation is less distinct. In this facies type, peaks are not exactly overlapping, pointing to an increased lateral variability. However, the important facies boundaries of the carbonate-rich sandy facies (transition zones 1 and 2) are well visible in the ERT data. The same picture emerges when comparing the ERT data to the electrical resistivity measurement from the borehole BWS-I2 (Fig. 2), which was performed in March 2015.

\section{Discussion}

\section{Interpretation of macro- and microstructures}

The microstructural investigations carried out within the scope of this work show that the lithological-structural homogeneity/heterogeneity of a claystone formation, relevant for capturing the variability of thermomechanical and hydraulic properties, is mainly a question of the scale of observation. The examined claystone samples show a structural-compositional variability on the $\mathrm{cm}$ to $\mathrm{dm}$ range, occasionally up to the $\mathrm{m}$ range, which is reflected in both the mineralogical-geochemical and geophysical (geoelectrical) datasets. The vertical variation, subperpendicular to bedding, reflect changes in the depositional conditions (including environmental aspects and changes in sea level) and diagenetic processes through time (Lauper et al. 2018, 2020).

Two end members characterize the investigated facies types of Opalinus Clay: The clearly homogenous shaly facies 1 and the much more heterogeneous carbonate-rich sandy facies, which differ both in microstructure, geochemical and geophysical parameters. The sandy facies 1 is located between these two end members. Homogeneous claystone, free of sandy or carbonaceous layers, occurs in the lower part of the investigated profile (shaly facies 1 ). This facies is characterized by a very small grain size of the clayey matrix, which can no longer be resolved by optical microscopy. Larger components $(>10 \mu \mathrm{m})$ frequently occurring in the matrix include iron sulfides (pyrite), carbonate particles, fossil shells and quartz grains. The iron sulfides have presumably been formed (early) diagenetically under anoxic conditions. Throughout the section, we observed several steep or gradual variations in grain size, carbonate and/or clay mineral content. Increased detrital input in form of thin silty-sandy layers was observed in the shaly facies 2 in the upper part of the profile. Especially the carbonate-rich sandy facies and the sandy facies 1 show a higher proportion of silty-sandy layers alternating with clay-rich intervals. Sedimentary structures can include pyritized burrows, continuous or thinning-out sand layers or larger biogenic carbonate fragments. Chaotic or disrupted bedding might result from bioturbation or early sedimentary landslides (slumping). Coarser beds that thin out are associated with storm events (Wetzel and Allia 2003), pointing to deposition close to the storm-wave base (Lauper et al. 2018 and references therein). The observed carbonate cementation of the silty-sandy layers is dominant in the thicker beds of sandy facies 1 , but does not occur consistently in the shaly facies 2 . This applies in particular to bioturbated structures and to thin sand layers.

\section{Geochemistry and mineralogical rock composition}

The obtained mineralogical and geochemical data largely support the petrographic-structural studies of this work and the observations made in Galletti and Jaeggi (2019). Generally, $\mathrm{SiO}_{2}, \mathrm{Al}_{2} \mathrm{O}_{3}, \mathrm{Fe}_{2} \mathrm{O}_{3}$ and a high CEC (as a measure of retention capacity) correlate with a high amount of clay minerals. In the clay-rich samples, elevated iron content can be attributed to the presence of pyritized burrows and finely disseminated framboidal aggregates of pyrite. On the other hand, $\mathrm{CaO}, \mathrm{MnO}$ and $\mathrm{Zr}$ correlate with carbonate-rich or detrital-grain-rich sand layers. For both shaly facies types, the $\mathrm{MgO}$ content is bound to the clay-rich matrix of the Opalinus Clay (Kneuker et al. 2017). Zr is interpreted as an indicator for the presence of detrital grains. This corresponds well to a steady increase in $\mathrm{Zr}$ towards the sandy facies type, showing the highest amount of detrital input, documented by quartz-rich, silty-sandy layers. The decrease in CEC in the carbonate-rich sandy facies can be attributed to a decreasing content of swellable clay minerals (e.g. Frederickx et al. 2018) and correlates well with a decreasing $\mathrm{Al}_{2} \mathrm{O}_{3}$. This might have an impact on radionuclide retention capacity and swelling capacity, the latter especially important for resealing of natural fault planes and artificial fractures. The cores gave opportunity to study both important transitions from the shaly facies 1 towards the carbonate-rich sandy facies (sharp transition zone 1) and the more gradual and previously seldom sampled transition from the carbonaterich sandy facies towards the sandy facies 1 (transition zone 2). Mineralogical and geochemical investigations revealed a modified composition of carbonates (including extensive cementation) in these intervals. In addition to omnipresent calcite, diagenetic pyrite nodules and siderite, ankerite and kutnohorite were observed in transition zone 1. In transition zone 2 enrichments of Mg-rich ankerite and kutnohorite were found in addition to calcite. This was confirmed by 
the geochemical data, indicating enrichments of $\mathrm{Fe}_{2} \mathrm{O}_{3}$ and $\mathrm{MnO}$ in transition zone 1 and of $\mathrm{MgO}$ and $\mathrm{MnO}$ in transition zone 2 (Fig. 7).

Variations in geochemical composition can be further visualized using a ternary diagram according to Brumsack (1989), that is based on the three main components $\mathrm{CaO}$ (proxy for carbonate), $\mathrm{SiO}_{2}$ (proxy for quartz) and $\mathrm{Al}_{2} \mathrm{O}_{3}$ (proxy for alumosilicates like clay minerals) (Fig. 10). The results presented in the preceding sections and in Fig. 10 confirm that the shaly facies 2 and a few samples from the carbonate-rich sandy facies are compositionally closely related to the most homogenous facies type of the Opalinus Clay, the shaly facies 1 . In contrast, the sandy facies 1 and the carbonate-rich sandy facies represent the more heterogeneous endmembers (including a high lithological variability with distinct variations in element distribution and CEC) with probably altered material and/or barrier properties, when compared with the well characterized shaly facies 1 . This is also reflected by the structural studies, which revealed an intercalation of carbonaceous-sandy layers and clay-rich parts alternating on the $\mathrm{cm}$ to $\mathrm{dm}$ scale (compare to Fig. 5). The shaly facies 1 represents the most homogenous area in terms of composition, as compared to the carbonate-rich and sandy facies types.

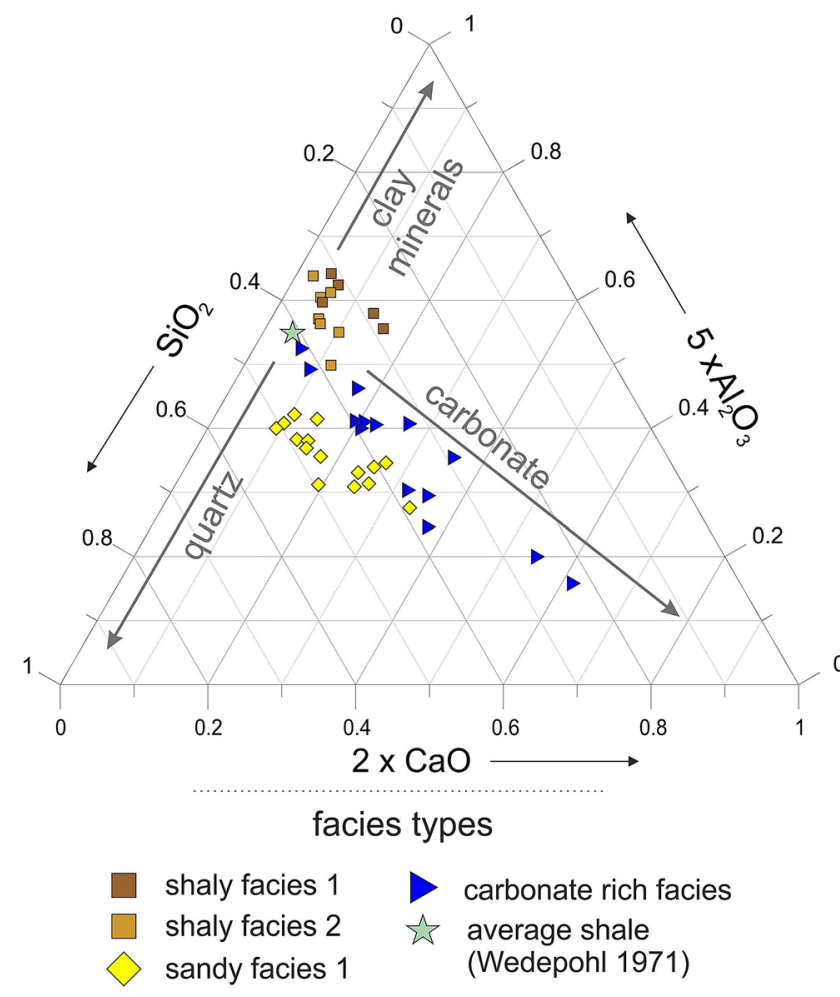

Fig. 10 Ternary diagram $\mathrm{SiO}_{2}-5 \times \mathrm{Al}_{2} \mathrm{O}_{3}-2 \times \mathrm{CaO}$ according to Brumsack (1989), showing the vertical variability for the different facies types (left) and subfacies types (right) of the Opalinus Clay,
The new results are consistent with previously published data and support the classification of the Opalinus Clay at the Mont Terri site into major facies types and further into subfacies types (see Sect. Intra-facies variability in the Opalinus Clay).

\section{Intra-facies variability in the Opalinus Clay}

The description of the geological subunits (facies types) in claystone has been extended with the introduction of the subfacies types, allowing a fine-resolution characterization within each facies type. Individual subfacies types are characterized by distinctive colors, grain size, degree of bioturbation, sedimentary structure and mineralogical composition (Lazar et al. 2015). For the present study, we successfully applied the classification of subfacies types according to Lauper et al. (2018) and introduced a new subfacies type (Fig. 4). This was necessary to capture the composition of the shaly facies 2, not included in the study of Lauper et al. (2018). The subfacies concept is well suited to capture the structural and compositional intra-facies variability of the investigated drill cores and is additionally confirmed by the good correlation with geochemical analyses and ERT data (Fig. 2).

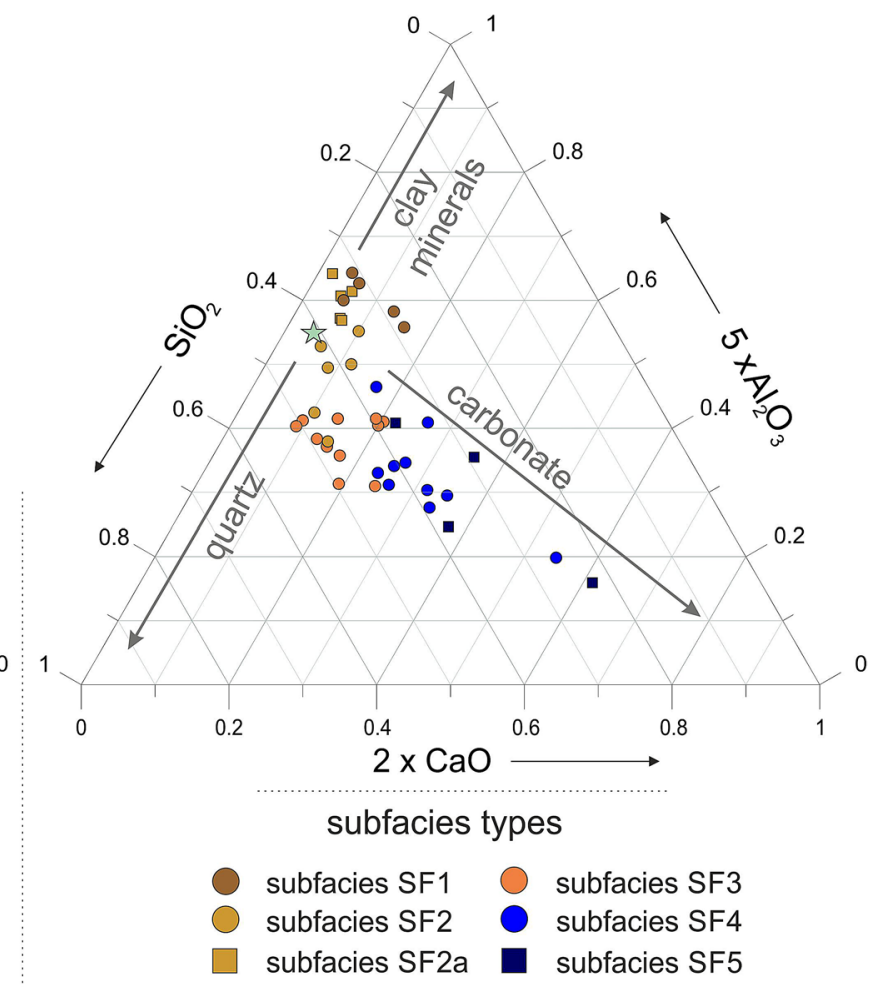

based on XRF measurements from the BAD-2 profile. Composition of the average shale according to Wedephol (1971) 
The present study, together with the investigations of Lauper et al. (2018), reveal a rather high intra-facies heterogeneity, especially for the carbonate-rich sandy facies and the sandy facies type 1 . In contrast, the shaly facies 1 is the most homogenous facies type of the investigated claystone sequence. Here, in accordance with Lauper et al. (2018), only one subfacies type (SF1) and few diagenetic carbonate interlayers showing cone-in-cone fabric were observed.

Not surprisingly, the trends in major element composition (Sect. Geochemistry and mineralogical rock composition) are reflected by the results when broken down into the six subfacies types (Fig. 10). The subfacies type SF1 and the newly defined subfacies type SF2a are dominated by clay minerals and quartz. The subfacies type SF2 and especially $\mathrm{SF} 3$ show a higher $\mathrm{Si} / \mathrm{Al}$ ratio, the subfacies types SF4 and SF5 are characterized by increased carbonate content, all consistent with the petrographic observations. The composition of the "average shale" according to Wedephol (1971) is located close to the argillaceous-siliceous claystones of the subfacies type SF2. The trends in geochemical distribution of distinct elements independently confirm the (micro)structurally based assignment of the samples to a certain subfacies type, which was demonstrated as well by Lauper et al. (2018). A summary of the structural-compositional characteristics including trends in resistivity within the individual subfacies types of Opalinus Clay can be found in Fig. 4.

The established subfacies model is valid for the rock laboratory scale. The subfacies types applied in the present study should be regarded as a preliminary classification of the Opalinus Clay at the Mont Terri site. For transition to other localities, they need to be confirmed and/or modified in future studies (cf. Lauper et al. 2020).

\section{Lateral structural-compositional variability}

Lateral layer variations (parallel to bedding) reflect the spatial distribution of depositional conditions with regard to the sedimentation area. First statements on lateral variability can be made based on drill core investigations of thin carbonaterich or silty-sand layers. As our observations have shown, some of these thin features are not continuous, as they are not exceeding the core diameter. However, a comparison with data from neighboring boreholes indicates that the majority of the larger (subfacies) scale structures is laterally traceable; this is true especially for the sandy facies 1 (Figs. 2 and 9). With few exceptions, almost the same structures were detected in the geological and geophysical datasets from different boreholes (Fig. 9). The correlation is less clear for the carbonate-rich sandy facies, in this case not every peak overlaps in the ERT curves pointing to an increased lateral intra-facies variability (in addition to the high vertical variability).
In addition, the data suggest that not all sand layers of the sandy facies thin out laterally after a few $\mathrm{cm}$ or $\mathrm{dm}$, and; thus, there is a stronger lateral continuity than previously assumed, at least for the thicker layers $>15 \mathrm{~cm}$ (cf. Jaeggi et al. 2014). The good lateral continuity of the transition zone 1 (at the base of the carbonate-rich sandy facies) is indeed well known, as these carbonate-rich beds are used as stratigraphic marker horizons throughout the Mont Terri rock laboratory (e.g. Galletti and Jaeggi 2019). This also includes a nodulous pyrite layer at the base of transition zone 1 (compare to Hostettler et al. 2017; Jaeggi et al. 2020). Based on the results of the present study, we can confirm the rather low lateral variability inside the sandy facies 1 and the increased intra-facies variability within the carbonate-rich sandy facies, for the latter on both vertical and lateral scale. This is not the case for the diagenetic carbonate beds showing cone-in-cone fabric in the homogenous shaly facies 1 , as they cannot be correlated between BAD-2 and BWS-I2 (Fig. 2). A mapping of underground galleries or outcrops, if applicable, can provide more detailed information on lateral continuity as compared to a correlation based on the borehole investigations (compare to Müller and Jaeggi 2012; Jaeggi et al. 2020). Despite this, the correlation of both important transition zones (facies boundaries of the carbonate-rich sandy facies) is perfectly possible using the set of methods applied in the present study.

The applied facies and subfacies model is valid for the rock laboratory scale, as the lithology of the Opalinus Clay varies laterally on a regional scale. The carbonate-rich sandy facies is typical for the Jura region in western Switzerland; it does not occur in the proposed siting regions for a deep geological repository in Northern Switzerland. This might be explained with the proximity of the Burgundy High to the west (Lauper et al. 2020) and with differential subsidence resulting in an increased W-E variability of the Opalinus Clay in Switzerland (Lauper et al. 2018 and references therein).

\section{Correlation of geophysical data with rock fabrics}

Previous investigations have shown that variations in geoelectrical measurements on Opalinus Clay can be attributed either to structures related to natural faults, artificial fractures or to small-scale sedimentary heterogeneities in the drill core profile (e.g. Kneuker et al. 2017; Schuster et al. 2017, 2019).

Electrical resistivity can depend upon a multitude of factors, including lithology, porosity, connectivity of pores, nature of the pore fluids and the presence of ore minerals in the rock matrix (Telford et al. 1990). In the investigated claystones, the varying ERT signal can be attributed to the differences in clay mineral content. Due to the large specific internal surface of clay minerals and the associated interface 
conductivity, clay-rich intervals with an elevated saturation show a high conductivity and correspondingly a low resistivity of $<10 \Omega \mathrm{m}$. Other factors like porosity and the water saturation are in turn dependent on the clay mineral content (Archie 1950).

The ERT profiles suggest that both the shaly facies 1 and 2 (including subfacies types SF1, SF2a and SF2) are characterized by resistivity $<10 \Omega \mathrm{m}$ with little variation (Fig. 2). In contrast, thicker limestones or carbonate layers, especially when well cemented, are characterized by a resistivity > $40 \Omega \mathrm{m}$ (Telford et al. 1990; Keller and Frischknecht 1996). These intervals correspond to the subfacies types SF4 and SF5. This is also the case for the two lithofacies transitions towards the carbonate-rich sandy facies, which stand out as high-resistivity zones $(>40 \Omega \mathrm{m})$ in the geoelectrical profiles. These intervals are characterized by increased cementation; in addition mineralogical and structural investigations revealed a modified composition of diagenetic carbonates (Fe-rich ankerite and Mn-rich kutnohorite) in these intervals (see Sect. Mineralogical-geochemical rock composition). However, we do not expect that this compositional difference had a direct influence on the ERT signal for the investigated profiles (compare to Verwer et al. 2011 and Regnet et al. 2019). The high-resistivity values might be related to the increased level of diagenetic carbonate cementation and the correspondingly low clay mineral content (resulting in a low interface conductivity, low porosity and a decreased water content).

The mean resistivity in the sandy facies $(4.70 \mathrm{~m}$ to $19.40 \mathrm{~m}$ ) is significantly higher (ca. $15 \Omega \mathrm{m}$ ); here the heterogeneity in form of calcareous-siliceous layers (SF3 and SF4) is considerably stronger (Fig. 9). The average level of resistivity in the carbonate-rich sandy facies ranges between the values of the shaly and the sandy facies types. This decrease (in comparison to the sandy facies) was also reported by Schuster et al. (2017) and might be explained by the presence of clay-rich interlayers (SF2), which are common in the carbonate-rich sandy facies. They are the reason for the increased lithological heterogeneity in the latter, also reflected by the high variation of amplitudes in resistivity data, resulting in a more pronounced contrast to carbonaterich, high-resistivity layers and their better visibility in the ERT data in comparison to the sandy facies 1 . This illustrates that both the composition of the subfacies type and the overall composition of the facies type have to be taken into account. A comparison with the adjacent borehole BGC-2 and BWS-I2 illustrates the good reproducibility of the geoelectric data (Fig. 9). Overall, the resistivity values obtained for the sandy and carbonate-rich sandy facies are close to published values derived for the Mont Terri rock laboratory (e.g. Schuster et al. 2017).

Fractures of the excavation damaged zone (EDZ) in the unsaturated parts around the underground galleries are generally well visible and characterized by a high resistivity $>20 \Omega \mathrm{m}$ (e.g. Kneuker et al. 2017). However, this is not the case for the ERT data from the BAD-2 borehole. This speaks against a very pronounced unsaturated zone in BAD2, although typical EDZ fracture patterns were observed down to $1.5 \mathrm{~m}$ drill core depth. Fractures and faults in the deeper part of a drill core, where the rock is saturated, are visible in ERT profiles only as moderately elevated or even low resistivity as in the case of the Main Fault (Kneuker et al. 2017). The increased lithological variability in the sandy or carbonate-rich sandy facies types probably complicated the detection of fault structures within the ERT signal. Nevertheless, the structural studies of the BAD-2 drill core confirmed that faults are rare in both the sandy and the carbonate-rich sandy facies, larger fault zones including scaly clay are lacking.

The geophysical measurements provide robust results regarding the detection and in situ characterization of structural and sedimentary heterogeneities in claystone. To distinguish between fractured/faulted domains and variations in the mineralogical composition, a correlation with ultrasonic interval velocity measurements or other geophysical logs would be helpful (e.g. Kneuker et al. 2017; Schuster et al. 2017, 2019). Unfortunately, this type of measurements was not performed in the BAD-2 borehole.

\section{Fault occurrence and heterogeneities}

Claystone formations are composed of clay-rich intervals, silty-sandy or carbonate-rich intercalations and therefore include a variety of mechanically distinct intervals and boundaries (Klinkenberg et al. 2009; Gale et al. 2014; An et al. 2020). Claystone formations with high clay content tend to have lower strength with regard to shear and tensile failure (Sone and Zoback 2011) and generally show reduced frictional resistance by bed-parallel sliding (Orellana et al. 2018a, b). Isolated quartz or carbonate grains in claystone are likely to have less of an effect on strength than constituents in contact (silty-sandy layers, quartz or carbonate cements) (e.g. Kaufhold et al. 2013; Gale et al. 2014; Zhang and Laurich 2020). Owing to its tectonic history (e.g. Nussbaum et al. 2011, 2017 and references therein), the Opalinus Clay at Mont Terri is affected by several individual faults and fault zones.

In the analyzed core material, deformation was accommodated mainly by frictional sliding, documented in the formation of microshears and slickensides (e.g. Engelder et al. 1975; Laurich et al. 2014; Kneuker et al. 2017), consistent with experimental results (Orellana et al. 2018a). Slickensided shear surfaces show differences in surface roughness/ shininess, step length and step height. All investigated faults appear macroscopically closed, but can be reactivated or disintegrate under excess stress (e.g. during drilling) into 
$\mathrm{cm}$-sized debris. It was found that most fault planes occur in the shaly facies types (Fig. 6). The observed fault density (around $0-9 \mathrm{~m}^{-1}$ ) is consistent with the data from Kneuker et al. (2017), who report a fault density of $1-8 \mathrm{~m}^{-1}$ outside the Main Fault in Mont Terri rock laboratory.

With increasing quartz content, an increased roughness of the fault surfaces was observed (Fig. 6). This waviness results from the different stiffness of components inside the rock material, e.g. early diagenetic nodules and silt-rich or carbonate lenses that formed during compaction of the sediments and thin clay sheets anastomosing around the larger grains and sand lenses. If the differential stress during shearing is not sufficient to activate fracturing of the rigid components, significant bedding parallel slip is hindered, implicating a rather small displacement along those types of faults. This is consistent with Kaufhold et al. (2013), who observed for samples from the sandy facies an increase in shear strength with increasing carbonate content. This is also consistent with experimental results from An et al. (2020), who found that phyllosilicate-poor shale gouges exhibited higher frictional strength as compared to phyllosilicate-rich gouges.

Palaeostress measurements in the Mont Terri rock laboratory by Nussbaum et al. (2011) revealed top to NW thrust movements with a shortening axis of $330^{\circ}-150^{\circ}$ (parallel to the strike line of $S_{0}$ ) for the principal deformation phase. Our observation of dip-slip and reverse or thrust movements are therefore in good agreement with Nussbaum et al. (2011) and Laurich et al. (2014). This further indicates that the majority of observed faults are related the folding of the Jura fold belt as a consequence of the propagation of the Alpine foreland towards NNW, starting in the Middle Miocene (Becker 2000; Nussbaum et al. 2011). Veins as evidence for syntectonic palaeo-fluid transfer were detected exclusively in the shaly facies 1 of the BAD- 2 cores, but they are known from the carbonate-rich sandy facies (window in gallery 98) or from other localities/facies types inside the Mont Terri rock laboratory (Pearson et al. 2003; Clauer et al. 2017; Mazurek and de Haller 2017; Jaeggi et al. 2020). The presence of veins document enhanced palaeo-permeability during fault activity, most probably at the time of folding of the Jura Mountains or during later fault reactivation.

With regard to subfacies types, most faults were observed in the clay-rich subfacies types SF1, SF2 and SF2a. Even for the sandy and carbonate-rich sandy facies, faults occur predominately in the clay-rich and silty subfacies types SF2 and SF3 (Fig. 2). This is consistent with Jaeggi et al. (2020) and Kneuker et al. (2017), who found that fault zones in the Opalinus Clay often correlate with an increased clay content; Kneuker et al. (2017) additionally confirmed a corresponding low electrical resistivity in ERT data. The prominent Main Fault is also located in the shaly facies 1 (subfacies type SF1; Laurich et al. 2014, Fig. 1), the facies type with the highest amount of clay minerals. In terms of fault orientation, the most dominant occurrence of faults within the shaly facies 1 is subparallel to bedding $\mathrm{S}_{0}$ (Nussbaum et al. 2011; Jaeggi et al. 2017), this represents also the orientation of the Main Fault structure. Most of these faults subparallel to $S_{0}$ are either reactivated bedding planes or faults dipping $5^{\circ}-10^{\circ}$ steeper than $S_{0}$ (Jaeggi et al. 2020). According to Lauper et al. (2018), the subfacies model may be used for an estimation of rock properties such as failure strength dependent on carbonate content. Kneuker et al. (2020) discovered that brittle fracturing could vary significantly with the presence of compositional heterogeneities on the $\mathrm{dm}$ to $\mathrm{m}$ scale in Lower Cretaceous claystones from Northern Germany. In the investigated cores from Opalinus Clay, small-scale faults indeed often accumulate next to heterogeneities, pointing to peak stresses along the transition zone towards carbonaterich or sandy intervals (facies and/or subfacies type scale).

In the rather complex Main Fault, located in the shaly facies 1 , repeated fault (re)activation led the formation of a very fine-grained, cohesionless fault gouge and to a fragmentation of the previously formed calcite veins (e.g. Laurich et al. 2014; Kneuker et al. 2017). Such features were not observed for the discrete brittle fault planes in the BAD-2 drill cores. Nevertheless, the high fault density continuing beyond $1.5 \mathrm{~m}$ borehole depth, thereby exceeding the EDZ, indicates that the artificial fracture system of the EDZ intermingled with natural fault planes present in the BAD-2 cores. For this zone, a local reactivation of shear planes during the excavation of the underground galleries, as reported in Nussbaum et al. (2011) and Thöny (2014) cannot be ruled out.

\section{Implications of the geological-geophysical investigations and their results}

Depending on their depositional history, claystone formations are characterized by a large number of small-scale facies changes and corresponding lithological transitions (e.g. Gale et al. 2014). Petrographic-structural studies together with geophysical borehole measurements form the basis for rock characterization and provide first indications for the compositional-structural variability. For the present study, the geological description has been extended with the introduction of the subfacies concept, allowing a high-resolution characterization of the claystone formation in question (Lazar et al. 2015; Lauper et al. 2018). A high lithological intra-facies variability subperpendicular to bedding is widespread, especially for the silt-rich, sandy and carbonate-rich parts of the investigated claystone sequences. These heterogeneities on the subfacies scale could have an impact on the barrier properties (e.g. mechanical behavior, retention capacity, behavior under thermal load). Of particular interest is the observed decrease in cation exchange capacity inside 
the carbonate-rich or sandy interlayers (e.g. Frederickx et al. 2018). This could have an impact on radionuclide retention and swelling capacity, the latter especially important for the resealing of natural fault planes and artificial fractures.

Deformation of the investigated claystones occurred localized along discrete brittle fault planes; the facies type can influence the fracture behavior and the characteristics of natural fault planes. It was found that most faults occur in the clay-rich facies types and intervals. This probably reflects the low shear strength of the investigated clay-rich sections which can be attributed to the anisotropy of the mechanical properties (Gautschi 2017), favoring the development of fault planes aligned subparallel to bedding (Orellana et al. 2018a; b). Brittle fault planes and lithological heterogeneities represent planes of mechanical weakness (Marschall et al. 2017), which are prone for reactivation (e.g. Orellana et al. 2018b). It was shown experimentally that increasing shear strain can lead to dilatancy and to a fault parallel permeability enhancement (Samuelson et al. 2009; Orellana et al. 2019) in agreement with in situ field observations (Guglielmi et al. 2017; Jeanne et al. 2018). The detection and detailed characterization of compositional-structural heterogeneities is therefore of particular importance for the evaluation of potential host rock formations. Their impact on barrier properties is an important subject and needs to be adequately investigated and considered in any long-term safety analysis.

\section{Conclusions}

The following conclusions can be drawn from the multidisciplinary investigations presented above.

- A high lithological intra-facies variability subperpendicular to bedding is widespread, especially for the sandy and carbonate-rich parts of the investigated claystone sequence.

- On the other hand, the data indicate a rather low lateral variability (parallel to bedding), except for the carbonate-rich sandy facies. Here, an increased compositionalstructural variability for both the vertical and lateral scale was observed.

- The observed intra-facies variability in the structural, geochemical and geophysical dataset is compatible with the new classification scheme of geological subunits proposed by Lauper et al. (2018).

- Varying resistivity in high-resolution ERT measurements can be attributed to differences in clay mineral and carbonate content. Especially the transition zones and facies boundaries can be precisely localized, the reproducibility of the measurements and observations was confirmed by a comparison with boreholes drilled in parallel.
- Structural heterogeneities include fault planes, deformation in the investigated claystones is localized along brittle faults. The facies type can influence the fracture behavior and the fabric of natural fault planes. It especially has an influence on the abundance of fractures.

- Both structural and compositional heterogeneities on the subfacies scale could have an impact on barrier properties (e.g. mechanical behavior, radionuclide retention capacity, swelling capacity, behavior under thermal load). Their detection is of particular importance for the evaluation of potential host rock formations.

Supplementary Information The online version contains supplementary material available at https://doi.org/10.1007/s12665-021-09708-1.

Acknowledgements Many thanks go to the swisstopo team (C. Nussbaum, D. Jaeggi, T. Theurillat and S. Schefer) for local site support and onsite core documentation. Boreholes were drilled by S. Sanchez and C. Fixar, clay samples were prepared by T. Faust and A. Heiner; thanks to R. Dohrmann, F. Korte and K. Ufer (all BGR) for help with the interpretation of the mineralogical-geochemical dataset and/or sample handling. Several colleagues participated in the geophysical measurements (in alphabetical order): H. Albers, U. Nowak, F. Schulte and T. Tietz (all BGR). Their efforts are kindly acknowledged. We further would like to thank B. Lauper (University of Fribourg) for fruitful discussions regarding stratigraphy and the subfacies concept and $\mathrm{J}$. Maßmann (BGR) for coordinating the AD experiment. We are grateful to D. Jaeggi (swisstopo) and G. Zulauf (Goethe University Frankfurt) for constructive comments on earlier versions of the manuscript. The authors would like to thank two anonymous reviewers for their helpful and constructive reviews, which helped to improve the quality of the present paper. The AD experiment received funding from the Federal Ministry for Education and Research (BMBF) under grant 03G0866A (GeomInt project). This study was supported by the German Federal Ministry for Economic Affairs and Energy (BMWi; 9Y2013020000).

Author contributions T.K. carried out sampling and the structural and mineralogical-geochemical investigations; M.F. performed the geophysical borehole measurements and the data processing. T.K. and M.F. contributed to the interdisciplinary interpretation of the presented results. T.K. took the lead in writing the manuscript, M.F. provided critical feedback; both authors shaped the manuscript substantially.

Funding Open Access funding enabled and organized by Projekt $\mathrm{DEAL}$. The AD experiment received funding from the Federal Ministry for Education and Research (BMBF) under grant 03G0866A (GeomInt project). This study was supported by the German Federal Ministry for Economic Affairs and Energy (BMWi; 9Y2013020000).

Availability of data and material The manuscript has data included as electronic supplementary material.

\section{Declarations}

Conflicts of interest The authors declare that they have no known competing financial interests or personal relationships that could have appeared to influence the work reported in this paper.

Open Access This article is licensed under a Creative Commons Attribution 4.0 International License, which permits use, sharing, 
adaptation, distribution and reproduction in any medium or format, as long as you give appropriate credit to the original author(s) and the source, provide a link to the Creative Commons licence, and indicate if changes were made. The images or other third party material in this article are included in the article's Creative Commons licence, unless indicated otherwise in a credit line to the material. If material is not included in the article's Creative Commons licence and your intended use is not permitted by statutory regulation or exceeds the permitted use, you will need to obtain permission directly from the copyright holder. To view a copy of this licence, visit http://creativecommons. org/licenses/by/4.0/.

\section{References}

An M, Zhang F, Elsworth D, Xu Z, Chen Z, Zhang L (2020) Friction of longmaxi shale gouges and implications for seismicity during hydraulic fracturing. J Geophys Res Solid Earth. https://doi.org/ 10.1029/2020JB019885

Archie GE (1950) Introduction to petrophysics of reservoir rocks. AAPG Bull 34:943-961

Becker A (2000) The Jura Mountains - an active foreland fold-andthrust belt? Tectonophysics 321:381-406

Bläsi HR, Moeri A, Bossart P (1996) Results of the phase 1 drilling campaign. Technical Report TR 96-01, Federal Office of Topography (swisstopo), Wabern, Switzerland

Boles A, van der Pluijm B, Mulch A, Mutlu H, Uysal IT, Warr LN (2015) Hydrogen and ${ }^{40} \mathrm{Ar} /{ }^{39} \mathrm{Ar}$ isotope evidence for multiple and protracted paleofluid flow events within the long-lived North Anatolian Keirogen (Turkey). Geochem Geophys Geosyst 16:1975-1987

Bossart P, Thury M (2008) Mont terri rock laboratory project, programme 1996 to 2007 and results. Rep Swiss Geol Surv 3:1-445

Bossart P, Bernier F, Birkholzer J, Bruggeman C, Connolly P, Dewonck S, Fukaya M, Herfort M, Jensen M, Matray JM, Mayor JC, Moeri A, Oyama T, Schuster K, Shigeta N, Vietor T, Wieczorek K (2017) Mont Terri rock laboratory, 20 years of research: introduction, site characteristics and overview of experiments. Swiss J Geosci 110:3-22

Brumsack HJ (1989) Geochemistry of recent TOC-rich sediments from the Gulf of California and the Black Sea. Geol Runds 78:851-882

Crisci E, Ferrari A, Giger SB, Laloui L (2019) Hydro-mechanical behaviour of shallow Opalinus Clay shale. Eng Geol 251:214-227

Clauer N, Techer I, Nussbaum C, Laurich B (2017) Geochemical signature of paleofluids in microstructures from main fault in the Opalinus Clay of the Mont Terri rock laboratory, Switzerland. Swiss J Geosci 110:105-128

Dohrmann R, Genske D, Karnland O, Kaufhold S, Kiviranta L, Olsson S, Plötze M, Sandén T, Sellin P, Svensson D, Valter M (2012) Interlaboratory CEC and exchangeable cation study of bentonite buffer materials: I. Cu(II)-triethylentetramine method. Clay Clay Miner 60:162-175

Engelder JT, Logan JM, Handin J (1975) The sliding characteristics of sandstone on quartz fault-gouge. Pure Appl Geophys 113:68-86

Frederickx L, Honty M, De Craen M, Dohrmann R, Elsen J (2018) Impact of mineralogy and pore water chemistry on the CEC of the boom clay formation (Belgium). Clay Clay Miner 66:449-465

Gale JF, Laubach SE, Olson JE, Eichhubl P, Fall A (2014) Natural fractures in shale: a review and new observations. AAPG Bull 98:2165-2216

Galletti M, Jaeggi D (2019) AD experiment: Drillcore documentation of boreholes BAD-1 and BAD-2. Technical Note TN 2019-06, Federal Office of Topography (swisstopo), Wabern, Switzerland
Gautschi A (2017) Safety-relevant hydrogeological properties of the claystone barrier of a Swiss radioactive waste repository: An evaluation using multiple lines of evidence. Grundwasser 22:221-233

Guglielmi Y, Birkholzer J, Rutqvist J, Jeanne P, Nussbaum C (2017) Can fault leakage occur before or without reactivation? Results from an in situ fault reactivation experiment at Mont Terri. Energy Procedia 114:3167-3174

Günther T, Rücker C, Spitzer K (2006) Three-dimensional modelling and inversion of DC resistivity data incorporating topography-II Inversion. Geophys J Int 166:506-517

Hostettler B, Reisdorf AG, Jaeggi D, Deplazes G, Bläsi H, Morard A, Feist-Burkhard S, Waltschew A, Dietze V, Menkveld-Gfeller U (2017) Litho-and biostratigraphy of the Opalinus Clay and bounding formations in the Mont Terri rock laboratory (Switzerland). Swiss J Geosci 110:23-37

Jaeggi D, Bossart P, Wymann L (2014) Kompilation der lithologischen Variabilität und Eigenschaften des Opalinus-Ton im Felslabor Mont Terri. Expertenbericht im Rahmen der Beurteilung des Vorschlags von mindestens zwei geologischen Standortgebieten pro Lagertyp, Etappe 2, Sachplan geologische Tiefenlager. Federal Office of Topography (swisstopo), Wabern, Switzerland

Jaeggi D, Laurich B, Nussbaum C, Schuster K, Connolly P (2017) Tectonic structure of the "main fault" in the Opalinus Clay, Mont Terri rock laboratory (Switzerland). Swiss J Geosci 110:67-84

Jaeggi D, Galletti M, Amacher F, Dunst R, Nussbaum C, Raselli R, Ringeisen M, Schefer S, Bossart P (2020) Gallery 2018: Excavation and geological documentation. Technical Report TR2018-04, Federal Office of Topography (swisstopo), Wabern, Switzerland

Jeanne P, Guglielmi Y, Rutqvist J, Nussbaum C, Birkholzer J (2018) Permeability variations associated with fault reactivation in a claystone formation investigated by field experiments and numerical simulations. J Geophys Res Solid Earth 123:1694-1710

Kaufhold A, Gräsle W, Plischke I, Dohrmann R, Siegesmund S (2013) Influence of carbonate content and micro fabrics on the failure strength of the sandy facies of the Opalinus Clay from Mont Terri (Underground Rock Laboratory). Eng Geol 156:111-118

Keller GV, Frischknecht FC (1996) Electrical Methods in Geographical Prospecting. Pergamon Press, London

Klinkenberg M, Kaufhold S, Dohrmann R, Siegesmund S (2009) Influence of carbonate microfabrics on the failure strength of claystones. Eng Geol 107:42-54

Kneuker T, Hammer J, Shao H, Schuster K, Furche M, Zulauf G (2017) Microstructure and composition of brittle faults in claystones of the Mont Terri rock laboratory (Switzerland): New data from petrographic studies, geophysical borehole logging and permeability tests. Eng Geol 231:139-156

Kneuker T, Blumenberg M, Strauss H, Dohrmann R, Hammer J, Zulauf G (2020) Structure, kinematics and composition of fluidcontrolled brittle faults and veins in Lower Cretaceous claystones (Lower Saxony Basin, Northern Germany): Constraints from petrographic studies, microfabrics, stable isotopes and biomarker analyses. Chem Geol 540:119501

Kolditz O, Frühwirth T, Görke UJ, Helbig C, Konietzky H, Maßmann J, Nest M, Rink K, Sattari A, Schmidt P, Pötschke D, Rink K, Steeb H, Wuttke F, Yoshioka K, Vowinckel B, Ziefle G, Nagel $\mathrm{T}$ (2021) GeomInt - Geomechanical integrity of host and barrier rocks - experiment, modeling and analysis of discontinuities. Environ Earth Sci, under review

Lauper B, Jaeggi D, Deplazes G, Foubert A (2018) Multi-proxy facies analysis of the Opalinus Clay and depositional implications (Mont Terri rock laboratory, Switzerland). Swiss J Geosci 111:383-398

Lauper B, Deplazes G, Vogel H, Jaeggi D, Wohlwend S, Ariztegui D, Foubert A (2020) Geochemical fingerprinting of key lithologies and depositional processes across the upper boundary of the 
Opalinus Clay (Aalenian, Middle Jurassic, northern Switzerland). Depos Rec. https://doi.org/10.1002/dep2.126

Laurich B, Urai JL, Desbois G, Vollmer C, Nussbaum C (2014) Microstructural evolution of an incipient fault zone in Opalinus Clay: insights from an optical and electron microscopic study of ion-beam polished samples from the Main Fault in the Mt-Terri Underground Research Laboratory. J Struct Geol 67:107-128

Lazar OR, Bohacs KM, Macquaker JH, Schieber J, Demko TM (2015) Capturing key attributes of fine-grained sedimentary rocks in outcrops, cores, and thin sections: nomenclature and description guidelines. J Sediment Res 85:230-246

Marschall P, Giger S, De La Vassière R, Shao H, Leung H, Nussbaum C, Trick T, Lanyon B, Senger R, Lisjak A, Alcolea A (2017) Hydro-mechanical evolution of the EDZ as transport path for radionuclides and gas: insights from the Mont Terri rock laboratory (Switzerland). Swiss J Geosci 110:173-194

Mazurek M, Hurford AJ, Leu W (2006) Unravelling the multi-stage burial history of the Swiss Molasse Basin: integration of apatite fission track, vitrinite reflectance and biomarker isomerisation analysis. Basin Res 18:27-50

Mazurek M, de Haller A (2017) Pore-water evolution and solutetransport mechanisms in Opalinus Clay at Mont Terri and Mont Russelin (Canton Jura, Switzerland). Swiss J Geosci 110:129-149

Meier LP, Kahr G (1999) Determination of the cation exchange capacity (CEC) of clay minerals using the complexes of Copper (II) ion with Triethylenetetramine and Tretraethylenepentamine. Clay Clay Miner 47:386-388

Minardi A, Crisci E, Ferrari A, Laloui L (2016) Anisotropic volumetric behaviour of Opalinus clay shale upon suction variation. Géotech Let 6:144-148

Müller P, Jaeggi D (2012) SO experiment: Sedimentary structure in the sandy facies of the Opalinus Clay at Mont Terri rock laboratory. Technical Note TN 2012-45, Federal Office of Topography (swisstopo), Wabern, Switzerland

Nesbitt BE, Muehlenbachs K (1989) Origins and movement of fluids during deformation and metamorphism in the Canadian Cordillera. Science 245:733-736

Nussbaum C, Bossart P, Amann F, Aubourg C (2011) Analysis of tectonic structures and excavation induced fractures in the Opalinus Clay, Mont Terri underground rock laboratory (Switzerland). Swiss J Geosci 104:187-210

Nussbaum C, Kloppenburg A, Caër T, Bossart P (2017) Tectonic evolution around the Mont Terri rock laboratory, northwestern Swiss Jura: constraints from kinematic forward modelling. Swiss J Geosci 110:39-66

Orellana LF, Scuderi MM, Collettini C, Violay M (2018a) Do scaly clays control seismicity on faulted shale rocks? Earth Planet Sci Lett 488:59-67

Orellana LF, Scuderi MM, Collettini C, Violay M (2018b) Frictional properties of Opalinus Clay: Implications for nuclear waste storage. J Geophys Res Solid Earth 123:157-175

Orellana LF, Giorgetti C, Violay M (2019) Contrasting mechanical and hydraulic properties of wet and dry fault zones in a proposed shale-hosted nuclear waste repository. Geophys Res Lett 46:1357-1366

Pearson FJ, Arcos D, Bath A, Boisson JY, Fernández AM, Gäbler HE, Gaucher E, Gautschi A, Griffault L, Hernán P, Waber HN (2003) Mont Terri Project - Geochemistry of Water in the Opalinus Clay
Formation at the Mont Terri Rock Laboratory. Geology Series 5 Federal Office for Water and Geology (FOWG), Bern, Switzerland

Regnet JB, David C, Robion P, Menéndez B (2019) Microstructures and physical properties in carbonate rocks: a comprehensive review. Mar Pet Geol 103:366-376

Reimann C, Birke M, Demetriades A, Filzmoser P, O'Connor P (2014) Chemistry of Europe's agricultural soils, part A. In: Methodology and Interpretation of the GEMAS Data Set. Geol Jb 102:21-523

Reisdorf AG, Hostettler B, Jaeggi D, Deplazes G, Bläsi HR, Morard A, Feist-Burkhardt S, Waltschew A, Dietze V, Menkveld-Gfeller U (2016) Litho- and biostratigraphy of the 250 m-deep Mont Terri BDB-1 borehole through the Opalinus Clay and bounding formations, St-Ursanne, Switzerland. Technical Report TR 2016-02, Federal Office of Topography (swisstopo), Wabern, Switzerland

Rücker C, Günther T, Spitzer K (2006) Three-dimensional modelling and inversion of dc resistivity data incorporating topography: I. Modelling. Geophys J Int 166:495-505

Samuelson J, Elsworth D, Marone C (2009) Shear-induced dilatancy of fluid-saturated faults: Experiment and theory. J Geophys Res Solid Earth 114:B12404

Schuster K, Amann F, Yong S, Bossart P, Connolly P (2017) Highresolution miniseismic methods applied in the Mont Terri rock laboratory (Switzerland). Swiss J Geosci 110:213-231

Schuster K, Furche M, Shao H, Hesser J, Hertzsch JM, Gräsle W, Rebscher D (2019) Understanding the evolution of nuclear waste repositories by performing appropriate experiments selected investigations at Mont Terri rock laboratory. Adv Geosci 49:175-186

Sone H, Zoback MD (2011) Visco-plastic properties of shale gas reservoir rocks: ARMA 45th U.S. Rock Mechanics Symposium, San Francisco, California. ARMA-11-417

Telford W, Geldart LP, Sheri RE (1990) Applied Geophysics, 2nd edn. Cambridge University Press, Cambridge

Thöny R (2014) Geomechanical analysis of excavation-induced rock mass behavior of faulted opalinus clay at the mont terri underground rock laboratory (Switzerland). Dissertation, ETH Zurich

Ufer K, Kleeberg R, Bergmann J, Dohrmann R (2012) Rietveld refinement of disordered illite/smectite mixed layered minerals with a recursive algorithm. II: powder pattern refinement and quantitative phase analysis. Clay Clay Miner 60:535-552

Verwer K, Eberli GP, Weger RJ (2011) Effect of pore structure on electrical resistivity in carbonates. AAPG Bull 95:175-190

Wedepohl KH (1971) Environmental influences on the chemical composition of shales and clays. Phys Chem Earth 8:307-333

Wetzel A, Allia V (2003) Der Opalinuston in der Nordschweiz: Lithologie und Ablagerungsgeschichte. Eclogae Geol Helv 96:451-469

Zhang CL, Laurich B (2020) Mechanical behavior of sandy facies of Opalinus Clay under different load conditions. J Rock Mech Rock Eng 12:223-241

Zulauf G, Palm S, Petschick R, Spies O (1999) Element mobility and volumetric strain in brittle and brittle-viscous shear zones of the superdeep well KTB (Germany). Chem Geol 156:135-149

Publisher's Note Springer Nature remains neutral with regard to jurisdictional claims in published maps and institutional affiliations. 